\title{
Paleomagnetism of the Joban Seamount Chain, Northwestern Pacific
}

\author{
Desiderius C. P. Masalu, Kensaku TAmaki, and Kazuo KobaYashi* \\ Ocean Research Institute, University of Tokyo, \\ 1-15-1 Minamidai, Nakano-ku, Tokyo 164, Japan
}

(Received June 17, 1992; Revised April 7, 1993)

\begin{abstract}
We conducted a detailed bathymetric and magnetic total force survey of five seamounts in the Joban seamount chain during cruise KH90-1 of the R/V HAKUHO MARU in 1990. The Joban seamount chain is situated to the east of the southern Japan Trench, trends along $N 53^{\circ} \mathrm{E}$ (oblique to magnetic anomaly lineations whose trend is $\mathrm{N} 68^{\circ} \mathrm{E}$ ) and extends over a distance of about $394 \mathrm{~km}$. We applied three-dimensional magnetic inversion to each seamount. The three northern seamounts show relatively complex magnetization structures, whereas the two southern seamounts show simple magnetization structures. The latter yielded reliable results with VGPs (Virtual geomagnetic pole) at $55.5^{\circ} \mathrm{N} / 348.9^{\circ} \mathrm{E}$ and $52.1^{\circ} \mathrm{N} / 352.4^{\circ} \mathrm{E}$. We estimated the ages of the two southern seamounts to be ca. 80 to 90 Ma by comparing their VGPs with known Pacific plate apparent polar wander path. We also estimated the ages for two guyot seamounts in the northern group to be ca. 110 to $130 \mathrm{Ma}$ by backtracking their crests along crustal age-depth curve to sea level. The Joban seamount chain apparently shows presence of at least two groups of inclinations. This suggests that the origin of this seamount chain is not the passage of the Pacific plate over a single stationary hotspot.
\end{abstract}

\section{Introduction}

Seamount paleomagnetism is a technique for estimating the mean direction of the magnetization vector and the intensity of magnetization of a seamount, for example by a linear least squares inversion of its magnetic anomaly (VACQUIER, 1962; TALWANI, 1965; PLOUFF, 1976; IsEZAKI and INOKUCHI, 1985). The first version of this technique (VACQUIER, 1962) which approximated the seamount body with rectangular prisms has been improved or extended by several investigators, to make the computational algorithm more efficient (TALWANI, 1965; PloufF, 1976; ISEZAKI and INOKUCHI, 1985). The results obtained are the three components of magnetization yielding a paleomagnetic pole and can be used like any other conventional paleomagnetic datum (e.g., UYEDA and RICHARDS, 1966; RICHARDS et al., 1967; VACQUIER and UYEDA, 1967; YAMAZAKI, 1988). Following the acceptance of the ideas of sea-floor spreading, the results of seamount paleomagnetism technique have provided valuable information in the study of the history of ocean basins and oceanic plates, such as the Pacific (SAGER, 1983; SAGER and KEATING, 1984; SAGER and PRINGLe, 1987, 1988; SAGER et al., 1992), from which fully oriented paleomagnetic samples are difficult to recover.

Linear chains of oceanic islands and seamounts have attracted considerable attention because such lines may record the passage of the lithosphere over fixed volcanic sources in the deep earth (Morgan, 1971; Duncan, 1981, 1984; Sager and Keating, 1984; Sager and Pringle, 1987, 1988; TUCHOLKE and SMOOT, 1990; PRINGLE, 1992). The linear chains of oceanic islands and/or seamounts need to be studied in detail in order to establish their origin of formation, and thus

* Present address: Japan Marine Science and Technology Center, 2-15 Natsushima-cho, Yokosuka, Kanagawa 237, Japan. 
to know whether they record the passage of the lithosphere over a fixed volcanic source or not. The best evidence that a linear chain records the passage of the lithosphere over a fixed volcanic source is an age progression (DUNCAN, 1981, 1984; Morgan, 1983; PRINGLE and DALRYMPLE, 1992; PRINGLE, 1992). The paleomagnetic data of seamount chain may also provide information about the origin of the seamount chain, for example by comparison of paleopoles with an apparent polar wander path.

We conducted a systematic geomagnetic and bathymetric survey of the Joban seamount chain in the northwestern Pacific during research cruise KH90-1 of R/V Hakuho-maru of the Ocean Research Institute, University of Tokyo. The Joban seamount chain is located to the east of the southern end of the Japan Trench in the northwestern Pacific (Fig. 1). It trends N53 ${ }^{\circ} \mathrm{E}$ which is inconsistent with models of the motion of the early Mesozoic Pacific plate. The data we collected are total geomagnetic force intensity, swath bathymetry, and other geophysical and geological data.

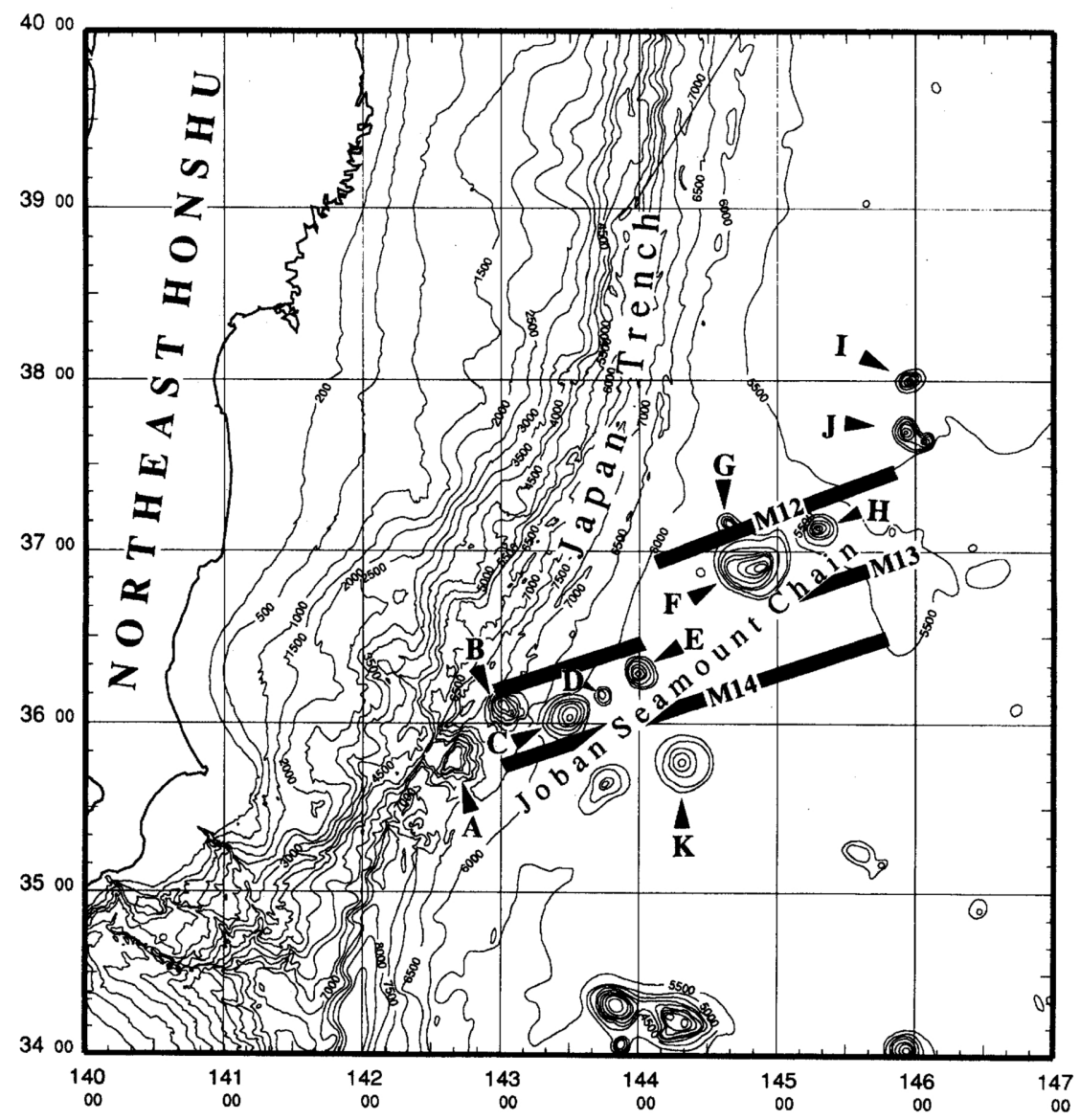

Fig. 1. Index map of the Joban Seamount Chain and its surroundings. $\mathbf{A}=$ Daiichi-Kashima Seamount; $\mathbf{B}=$ Katori Seamount; $\mathbf{C}=$ Daini-Kashima Seamount; $\mathbf{D}=$ Daisan-Kashima Seamount; $\mathbf{E}=$ Daiyon-Kashima Seamount; $\mathbf{F}=$ Iwaki Seamount; $\mathbf{G}=$ Futaba Seamount; $\mathbf{H}=$ Mizunagidori Seamount; $\mathbf{I}=$ Ryofu Seamount; $\mathbf{J}=$ Unnamed Seamount; $\mathbf{K}=$ Daiyon-Kashima Seamount. M12, M13 and M14 are magnetic anomaly lineations on this area, which have been traced from the profiles of observed magnetic anomalies and their ages assigned according to NAKANISHI et al. (1989). Bathymetry is based on GEBCO (General Bathymetric Chart of the Oceans) data. 
The existence of the Joban seamount chain has been known for some time (e.g., CHARTS 6312 and 1009 of the HYDROGRAPHIC DEPT. OF JAPAN), but had not been surveyed in detail before our cruise. This seamount chain extends over a distance of about $394 \mathrm{~km}$. The Joban seamount chain is formed by the following eleven seamounts (from northeast to southwest): Ryofu, an unnamed seamount, Mizunagidori, Iwaki, Futaba, Hitachi, Daiyon-Kashima, DaisanKashima, Daini-Kashima, Katori, and Daiichi-Kashima seamounts. The name for this seamount chain is after the Japanese district nearest to the chain (KOBAYASHI, 1991). We surveyed seven seamounts of the chain: Mizunagidori, Iwaki, Futaba, Hitachi, Daiyon-Kashima, Daisan-Kashima, and Daini-Kashima seamounts. Hitachi and Futaba seamounts have not been described in any existing bathymetric maps. Iwaki seamount is shown in the Hydrographic Department maps, although our study showed it to be a guyot.

There are several previous studies on the paleomagnetism of the Joban seamount chain. Mizunagidori seamount (also known as Bosei seamount) was found to have a small magnetic anomaly (TOMODA, 1974), but not studied in terms of paleomagnetism. Ryofu seamount has been studied by UYEDA and RICHARDS (1966) who concluded that the top part of this seamount may be weakly or completely non-magnetized. Paleomagnetic results of Diichi-Kashima seamount (UEDA, 1985) suggest that a considerable part of the top of this seamount must be non-magnetic. Katori seamount appears to have different magnetization components in its top and bottom parts (UEDA, 1985).

A few radiometric age dates are available from the Joban seamount chain. Daiichi-Kashima seamount has been estimated by the ${ }^{40} \mathrm{Ar}-{ }^{39} \mathrm{Ar}$ method (TAKIGAMI et al., 1989) to have formed about 120 Ma. Daini-Kashima and Ryofu seamounts have been dated by the K-Ar method to be $81 \mathrm{Ma}$ and 70 to $72 \mathrm{Ma}$ respectively (OzIMA et al., 1970; KANEOKA, 1971). More research has been done on Daiichi-Kashima seamount under the KAIKO project (LE PICHON et al., 1987) and by other investigators (e.g., MogI and NishizawA, 1980) and it is found that Daiichi-Kashima seamount is capped by limestone of about $100 \mathrm{~m}$ thick (PAUTOT et al., 1987) and is normally faulted (Mogi and NishizAWA, 1980; KoBAYASHI et al., 1987) due to being subducted at the axis of the Japan Trench.

More extensive scientific studies on seamounts and guyots, have been done in the western Pacific (e.g., UYEDA and RichARDS, 1966; VACQUIER and UYEDA, 1967; OzimA et al., 1977; SAger and Keating, 1984; SAger and Pringle, 1988, 1990; SAger et al., 1992; VAN WAasBERGEN and Winterer, 1992; Winterer et al., 1992; LiNCOLN et al., 1992). The abundance of seamounts and guyots in the western Pacific is unique in the world ocean-floor (SAGER et al., 1992; VAN WAASBERGEN and WINTERER, 1992; WinTERER et al., 1992). The origin of most of these Mesozoic age seamounts and guyots, which curiously seem to be aligned in chains in many cases, is still uncertain (SAGER et al., 1992; SAGER, 1992). Models for their origin that all call upon some kind of intraplate volcanism can be divided into two categories, those that call upon an unusual volcanic event or pulse, and those that do not (SAGER, 1992; SAGER et al., 1992). The later category of models presumes that most of the western Pacific seamounts were formed as the Pacific plate drifted over a congregation of hotspots presently located in region of French Polynesia in the Southeast Pacific (Crough, 1979; Henderson and Gordon, 1981), the modern Superswell (McNutT et al., 1990; Wolfe and MCNutT, 1991). They are result of the confluence of many hotspot tracks (SAGER et al., 1992). Their trends have been used by several investigators (e.g., Duncan and Clague, 1985; Fleitout and Moriceau, 1992) in trying to document the motion of the Pacific plate.

The former category of mechanism of origin of these seamounts and guyots includes the 'Darwin Rise' (MEnARD, 1964, 1984). Also, at least two other widespread Creataceous volcanic events or pulses, Aptian to Cenomanian (ca. 115-95 Ma) and Campanian to Maestrichtian (ca. 80-65 Ma) have been postulated to have taken place (WINTERER, 1976; SCHLANGER et al., 1981; REA and VALLIER, 1983). The former may have been particularly intense and included the 
formation of several of the western Pacific plateaus (TARDUNo et al., 1991). The two possible mechanisms of origin of abundant seamounts and guyots in the western Pacific differ mainly in that a volcanic pulse should be synchronous over a large area, while a hotspot track should display an age progression.

We have attempted to investigate the origin of the Joban seamount chain by the seamount paleomagnetism technique approach. In this paper we present the results of three-dimensional magnetic inversion analyses (TALWANI, 1965) of the seamounts forming the Joban seamount chain, and from these results and other data we try to constrain their magnetization structures and their origins. The results suggest that the Joban seamount chain was probably not formed by the passage of the lithosphere over a single fixed volcanic source.

\section{Geologic Setting}

The Joban seamount chain lies on the Pacific Plate off the Japan trench between $35^{\circ} 45^{\prime} \mathrm{N}$ and $38^{\circ} 00^{\prime} \mathrm{N}$ (Fig. 1). The Pacific plate is known to have generally moved northward and westnorthwestward and to have undergone little rotation since the Mid-Cretaceous period (HENDerson, 1985; Engebretson et al., 1985; Duncan and Clague, 1985). Furthermore some investigators have suggested that this plate moved southward in Jurassic and Early Cretaceous period (LARSON and LOWRIE, 1975; JARrARD and SASAJIMA, 1980; CoX and Gordon, 1984; Henderson, 1985; SAgER and PRINGle, 1988). The younger trajectory (0-78 Ma) of the motion of this plate manifested by the Hawaii-Emperor seamount chain is well constrained, while its older trajectory is poorly constrained (JARRARD and SASAJIMA, 1980; SAgER and PRIngLE, 1988).

The Joban seamount chain extends over a distance of about $394 \mathrm{Km}$ and strikes along $\mathrm{N} 53^{\circ} \mathrm{E}$ oblique to the strike of $\mathrm{N} 68^{\circ} \mathrm{E}$ of magnetic anomaly lineations (Fig. 1) on the surrounding oceanfloor (NAKANISHI et al., 1989, 1992). The ocean-floor on which this seamount chain is situated was formed between M14 and M11 (about 138 and $133 \mathrm{Ma}$ ) period according to KENT and GRADSTEIN's (1985) time scale. The observed depth of the ocean-floor on which the Joban seamount chain lies (Fig. 2) varies from $5800 \mathrm{~m}$ in the northern areas surrounding Mizunagidori, Iwaki and Hitachi seamounts to $6100 \mathrm{~m}$ in the southern areas surrounding Daisan-Kashima and DainiKashima seamounts. This variation of the observed ocean-floor depth may be caused by a gentle upward bending of lithosphere forming the outer swell east of the Japan Trench. Furthermore, a relatively large gap between Hitachi and Daiyon-Kashima seamounts (Fig. 2) appears to divide the seamounts on the Joban seamount chain into two groups: the northern group with Ryofu, an unnamed seamount, Mizunagidori, Iwaki and Hitachi seamounts and the southern group with Daiyon-Kashima, Daisan-Kashima, Daini-Kashima, Katori and Daiichi-Kashima seamounts.

Mizunagidori seamount is located roughly $15 \mathrm{~km}$ south of magnetic lineation M12 on sea floor interpolated to be $135.5 \mathrm{Ma}$. This seamount consists of two crests, the western and eastern crests, with crestal depths of $2300 \mathrm{~m}$ and $2800 \mathrm{~m}$ respectively. Mizunagidori seamount, surrounded by a moat on its southwestern side, is the only seamount on the Joban seamount chain which has been observed to be surrounded by a moat. Iwaki seamount, on $136 \mathrm{Ma}$ crust, is a guyot with crestal depth of $1700 \mathrm{~m}$. This seamount is the largest of all the seamounts forming the Joban seamount chain and has the shallowest crestal depth which slopes sharply on the northeastern side. The sharply sloping northeastern crestal bathymetry of Iwaki seamount (Fig. 2) may be indicative of a well developed barrier reef (KOBAYASHI, 1991). The crest of Iwaki seamount appears to be elongated along the magnetic lineation trend. Hitachi seamount is a conical guyot with crestal depth of $2400 \mathrm{~m}$, located about $10 \mathrm{~km}$ southwest of Iwaki seamount. Iwaki and Hitachi seamounts are connected at depth contours greater than $3600 \mathrm{~m}$. Daisan-Kashima seamount, with conical shape, has crestal depth of $3100 \mathrm{~m}$ and lies on crust of $137 \mathrm{Ma}$. Daini-Kashima seamount lies on 


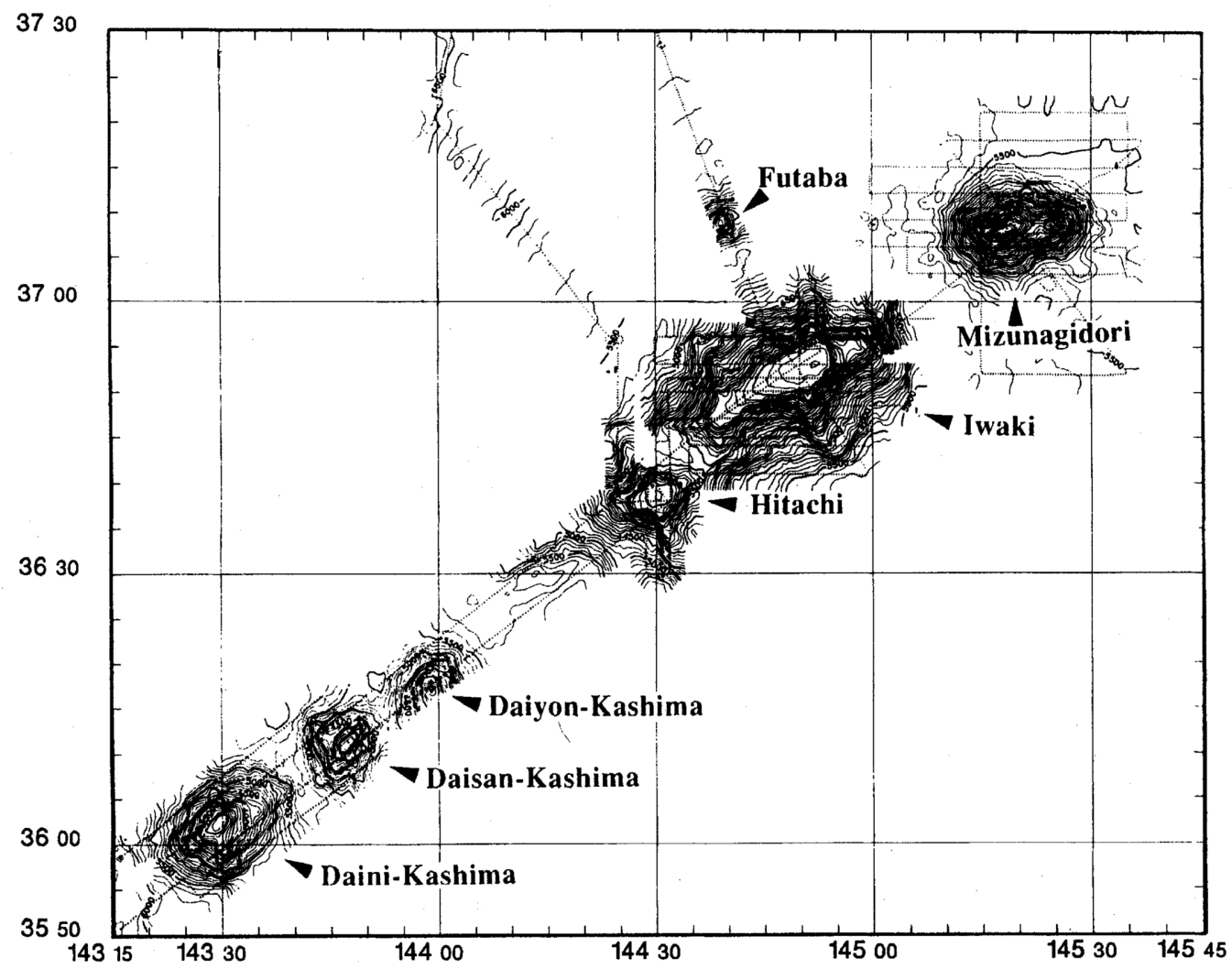

Fig. 2. Bathymetric map of the Joban Seamount Chain produced from Sea Beam bathymetric data collected during the survey in Leg 1 of cruise KH90-1. Contour interval is $100 \mathrm{~m}$. Dotted lines show ship's tracks.

crust of $137 \mathrm{Ma}$ in age and has a crestal depth contour of $2800 \mathrm{~m}$. This seamount is elongated along the trend of the Joban seamount chain.

Detailed description of the morphological characteristics of the Joban seamounts has been given by KoBAYASHI (1991). Daiichi-Kashima seamount, the most southwestern seamount on the Joban seamount chain, is now undergoing subduction at the axis of the Japan trench (KOBAYASHI et al., 1987). Submersible dives done on this seamount by the KAIKO project team found evidence of limestone material on the top of this seamount (KOBAYASHI et al., 1987). This may suggest the presence of limestone caps on other seamounts forming the Joban seamount chain.

\section{The Data and Method of Analysis}

For magnetic inversion, extensive bathymetry and magnetic anomaly maps are needed for a seamount. We collected total force and three components of geomagnetic field, Sea Beam swath bathymetry, and other geophysical and geological data. We had sufficient bathymetric and geomagnetic total force data to model Daini-Kashima, Daisan-Kashima, Hitachi, Iwaki and Mizunagidori seamounts, but not enough to model Futaba and Daiyon-Kashima seamounts. We computed magnetic anomalies from the observed total geomagnetic force data, with reference to the IGRF 1985 (IAGA DIVISION I WORKING GROUP 1, 1985). Anomaly values range between $-940 \mathrm{nT}$ and $570 \mathrm{nT}$ (Fig. 3). 


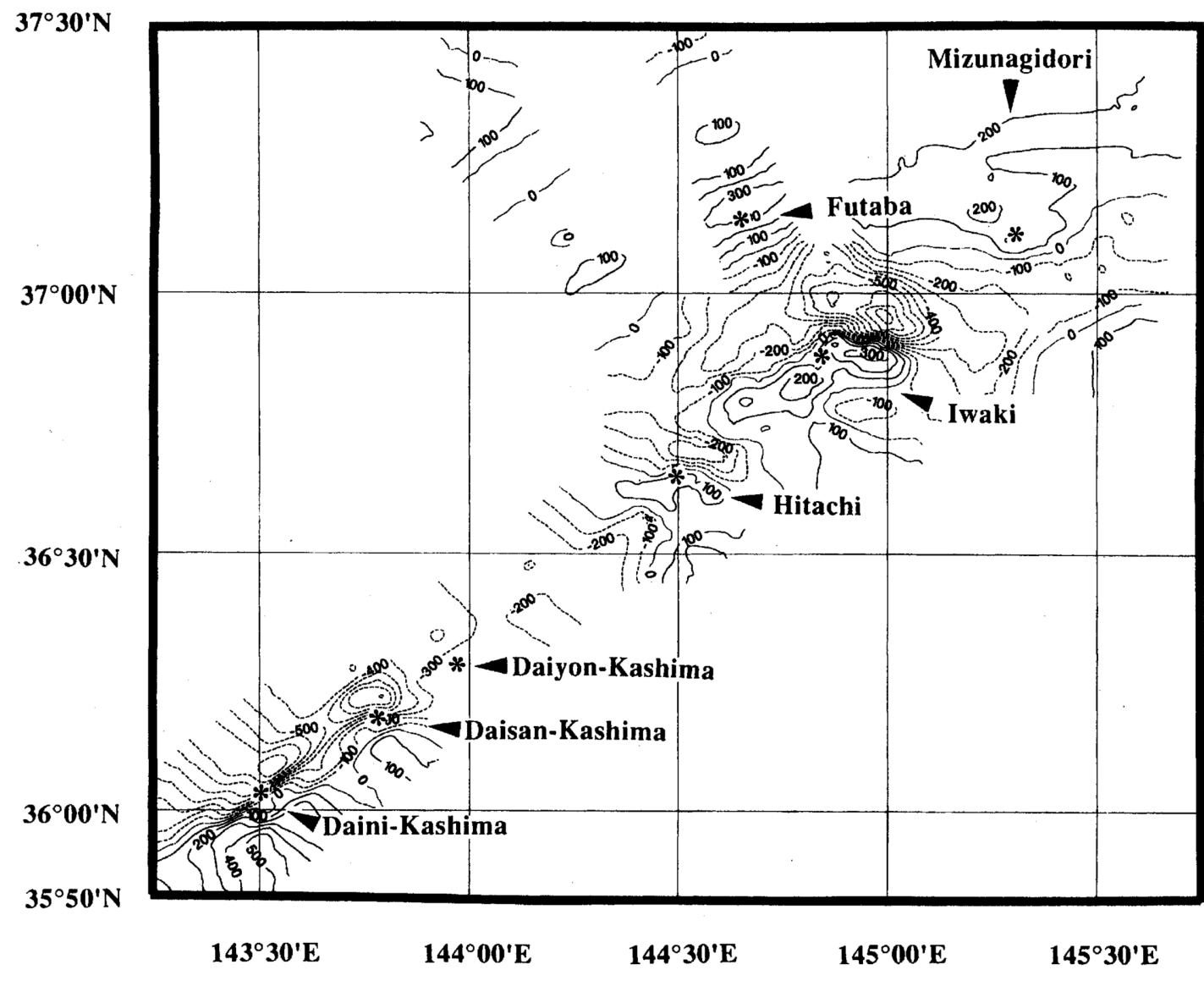

Fig. 3. Observed magnetic anomalies on the Joban Seamount Chain, produced from total force data collected during Leg 1 of cruise KH90-1 and reduced to the IGRF 1985. Dash contours represent negative magnetic anomalies. The zero contour anomaly is shown by a dotted line. Solid contours represent positive magnetic anomalies. Contour interval is $100 \mathrm{nT}$. Asterisks show the position of the topographic crest for each seamount.

We modeled magnetic anomalies over each seamount by applying a three-dimensional inversion of the observed sea surface anomalies using the method of TALWANI (1965). For mathematical simplicity, the TALWANI (1965) method and the other methods of seamount paleomagnetism technique (PLOUFF, 1976; IsEZAKI and INOKUCHI, 1985) mentioned above make as a basic assumption that the seamount body is uniformly magnetized (see RICHARDS et al. (1967), GrossLiNG (1970), Francheteau et al. (1970), Harrison et al. (1975), Sager (1983), Sager and KeatING (1984), PARKer et al. (1987), SAGER and PRiNgle (1988, 1990) and SAGER et al. (1992) for more pertinent informations on the other assumptions and their short falls). However, this assumption may not always be correct because some seamounts are nonuniformly magnetized (e.g., MCNutt, 1986; PrIngle et al., 1991). The nonuniform magnetization of seamounts has compelled investigators to find new methods and techniques of modelling them (e.g., SCHIMKE and Bufe, 1968; Emilia and Massey, 1974; Miles and Roberts, 1981; Sager, 1984; Shure et al., 1984; MCNUTT, 1986). The recent semi-norm method of PARKER et al. (1987) is perhaps the best method as it can account for both uniform and nonuniform magnetization components of a seamount body. It finds a magnetization model with the minimum amount of nonuniformity. 
However, it should be noted that this method makes assumption that nonuniform magnetization is random i.e. spatially uncorrelated. This is also rarely found in nature. Despite such advances in the method of three-dimensional analyses of magnetic anomalies, the methods of TALWANI (1965) and PLOUFF (1976) are still widely used because of their simplicity (e.g., UEDA, 1985, 1988; SAGER and PRINGLE, 1987, 1988; YAMAZAKI, 1988).

We approximated the bathymetric shape of each seamount by a stack of horizontal polygonal lamina spaced at vertical intervals of $100 \mathrm{~m}$. Our simulation approach was to begin with simple models by assuming uniform magnetization of the seamount body. In subsequent runs, we improved the models by addition of bottom depth contours and/or removal of top depth contours, until the best model was decided. We extended observed bottom depths of the seamounts by $100 \mathrm{~m}$ to $600 \mathrm{~m}$ by following their respective shape (slope) of the observed near-bottom depth contours (SAGER and PRINGLE, 1988). These bottom extensions can be accounted for by the thickness of sediments (HARRISON et al., 1975; SAgER, 1983, 1984; SAGER and KEATING, 1984; SAGER and PRINGLE, 1987). We removed top depth contours by assuming that the top part was weakly magnetized, in the same context as many previous workers (e.g., RICHARDS et al., 1967; HARRISON, 1971) have done. However, it was necessary to employ more complex models in simulating magnetic anomalies caused by Iwaki seamount by dividing the seamount into several blocks of magnetization. Moreover, in the case of Mizunagidori seamount it was necessary to remove the effect of magnetic lineations before attempting any modelling because this seamount has a very weak magnetic anomaly (Fig. 3 ).

We selected best models on the basis of several goodness test parameters and factors. Initially we gave high priority to models that yielded high values of the goodness-of-fit ratio (RICHARDS et al., 1967; VACQUIER and UYEDA, 1967). This parameter shows the degree of fitting between the observed and the calculated magnetic anomalies. Values of this parameter of over 2.0 are generally considered to imply that the paleomagnetic results calculated are reliable (e.g., SAGER and PRINGLE, 1987). Another parameter that we used is the correlation coefficient. This parameter shows how the observed and the calculated anomalies correlate to each other (UEDA, 1985). We assessed by eye inspection the residual magnetic anomalies and the fitness between the observed and the calculated magnetic anomalies. We selected as best models those models that yielded high goodness-of-fit ratio and correlation coefficient, and good agreement between the two dimensional distribution of the observed and the calculated magnetic anomalies.

\section{Models, Results of Inversions and Interpretation}

We modeled three of the seamounts, Daini-Kashima, Daisan-Kashima and Hitachi to be solely normally magnetized. The rest of the seamounts show complex magnetization structures. All seamounts yielded high values of goodness-of-fit ratios, except for Mizunagidori seamount, which yielded a small value of 1.70 . The best models of magnetization and the results for each seamount are summarized below.

\subsection{Daini-Kashima and Daisan-Kashima seamounts}

We modeled Daini-Kashima seamount (Figs. 4a-e) as uniformly magnetized with a normal polarity. We extended the observed bottom depth for this seamount from $6100 \mathrm{~m}$ to $6200 \mathrm{~m}$ (Figs. 4a and b) for the reasons we explained in Section 3. The negative peak for the observed magnetic anomaly (Fig. 4c) is at $-800 \mathrm{nT}$ and for the calculated magnetic anomaly (Fig. 4d) is at $-600 \mathrm{nT}$. The positive peak for the observed magnetic anomaly is at $500 \mathrm{nT}$ and for the calculated magnetic anomaly is at $400 \mathrm{nT}$. The residual magnetic anomalies (Fig. 4e) resulting from this model are not significant.

We also modeled Daisan-Kashima seamount (Figs. 5a-e) to be uniformly magnetized in a normal polarity. We extended the observed bottom depth for this seamount from $6000 \mathrm{~m}$ to 6300 

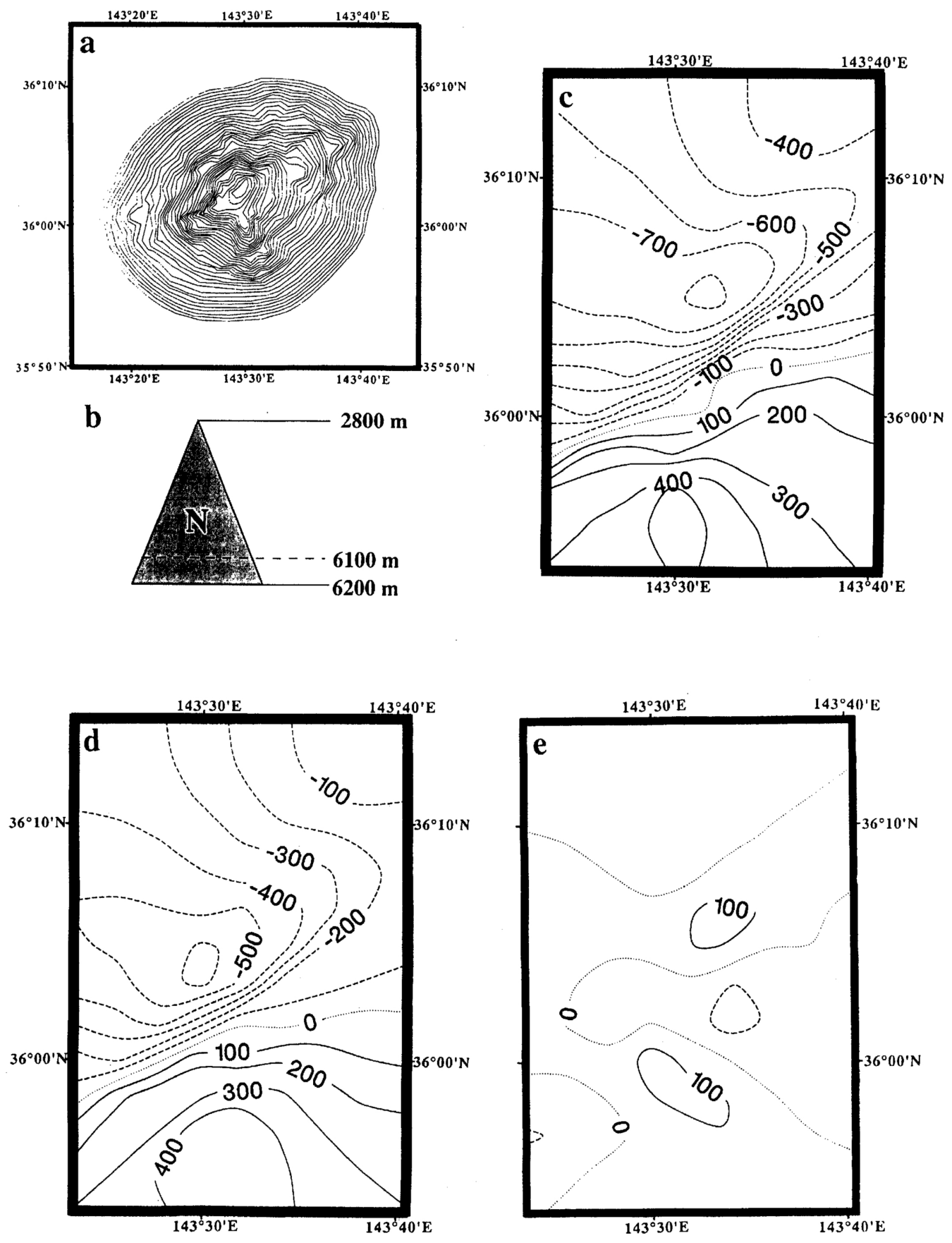

Fig. 4. Magnetic model of Daini-Kashima seamount. a) Polygonal lamina at intervals of $100 \mathrm{~m}$ used to approximate the bathymetry. b) A cartoon cross-section for the magnetization model. $\mathbf{N}=$ Normally magnetized. c) Observed magnetic anomalies. d) Calculated magnetic anomalies. e) Residual magnetic anomalies obtained by subtracting the best fitting uniform magnetization model (Table 1) from the observed anomalies. Dash contours represent negative anomalies. The zero contour anomaly is shown by a dotted line. Solid contours represent positive anomalies. Anomaly contour interval is $100 \mathrm{nT}$. 

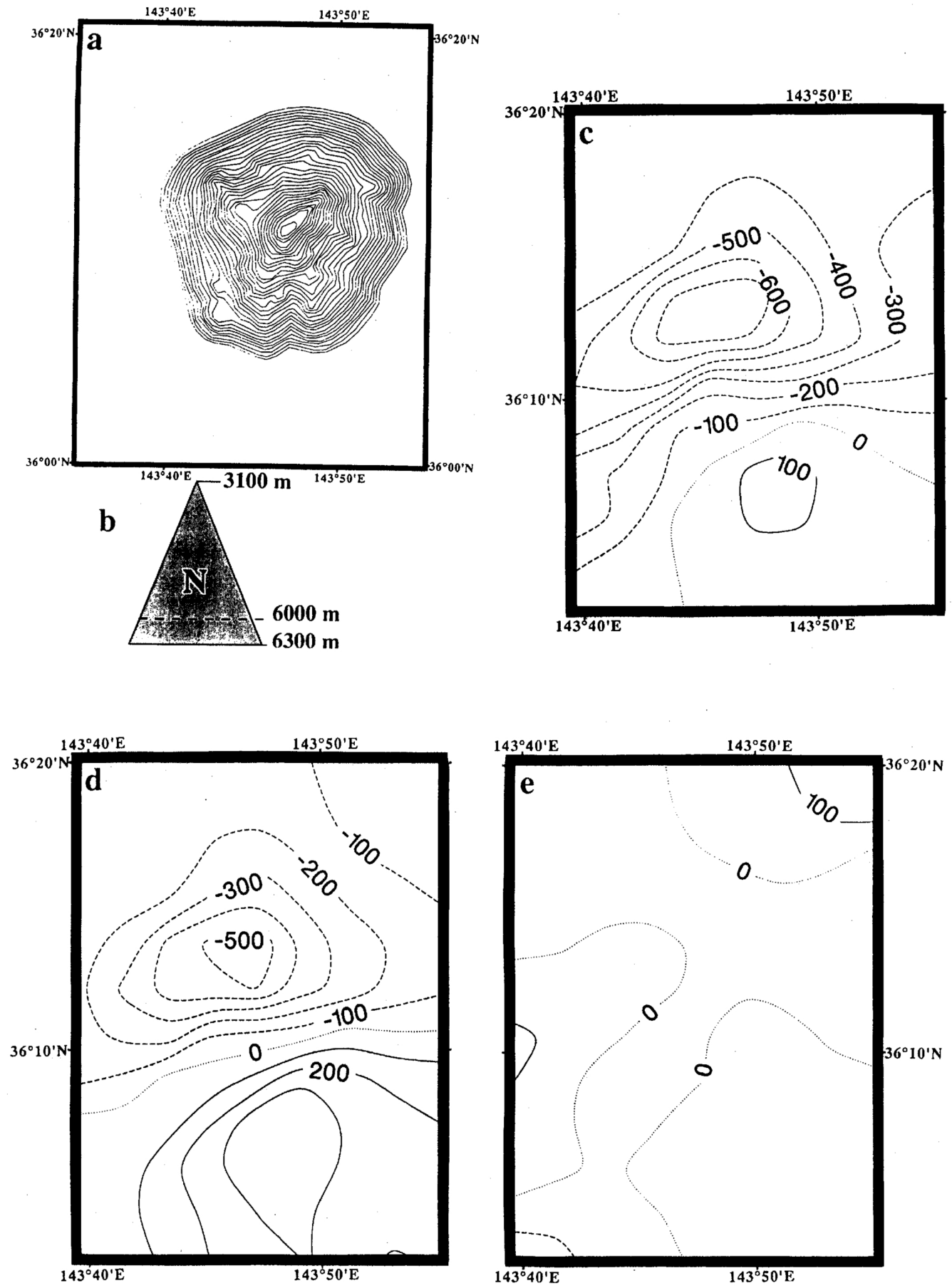

Fig. 5. Magnetic model of Daisan-Kashima seamount. a) Polygonal lamina at intervals of $100 \mathrm{~m}$ used to approximate the bathymetry. b) A cartoon cross-section for the magnetization model. c) Observed magnetic anomalies. d) Calculated magnetic anomalies. e) Residual magnetic anomalies obtained by subtracting the best fitting uniform magnetization model (Table 1) from the observed anomalies. Other figure panels are as in Fig. 4. 
$\mathrm{m}$ (Figs. 5a and b). The residual magnetic anomalies (Fig. 5e) for the best model of magnetization for this seamount are not significant.

These two seamounts yielded insignificantly different paleomagnetic results (Table 1) with high values of the G.F.R. (goodness-fit-ratio). Daini-Kashima seamount yielded a value of the G.F.R. of 4.60, and Daisan-Kashima seamount yielded results with a value of the G.F.R. of 5.10. The results obtained for these seamounts are thus considered reliable on the basis of their high G.F.R. values and other goodness test parameters and factors (Section 3).

Table 1. Magnetic inversion results for all seamounts.

\begin{tabular}{|c|c|c|c|c|c|c|c|c|c|}
\hline \multirow[b]{2}{*}{ Seamount } & \multirow[b]{2}{*}{ Run } & \multirow{2}{*}{$\begin{array}{l}\text { Magn. } \\
\text { Block }\end{array}$} & \multicolumn{3}{|c|}{ Paleomagnetic parameters } & \multicolumn{2}{|c|}{ VGP Position } & \multirow[b]{2}{*}{ G.F.R. } & \multirow[b]{2}{*}{ C.C. } \\
\hline & & & Dec. & Inc. & Int. $(\mathrm{A} / \mathrm{M})$ & Lat. $\left({ }^{\circ} \mathrm{N}\right)$ & Lon. $\left({ }^{\circ} \mathrm{E}\right)$ & & \\
\hline Daini-Kashima & 1 & All & 345.74 & 7.77 & 8.0 & 55.47 & 348.93 & 4.60 & 0.97 \\
\hline Daisan-Kashima & 1 & All & 342.76 & 3.28 & 10.41 & 52.11 & 352.42 & 5.07 & 0.97 \\
\hline Hitachi & 1 & All & 26.09 & 23.61 & 5.20 & 56.24 & 273.86 & 2.88 & 0.92 \\
\hline \multirow[t]{6}{*}{ Iwaki } & 1 & All & 28.04 & -10.77 & 7.05 & 40.24 & 287.02 & 2.10 & 0.74 \\
\hline & 2 & W & 1.90 & -12.59 & 5.03 & 46.71 & 322.08 & & \\
\hline & & $\mathrm{E}$ & 6.52 & -55.51 & 8.43 & 16.82 & 319.33 & 2.87 & 0.87 \\
\hline & 3 & W & 346.68 & -14.77 & 4.42 & 43.88 & 343.32 & & \\
\hline & & ET & 216.89 & 38.45 & 16.50 & -21.91 & 107.87 & & \\
\hline & & $\mathrm{EB}$ & 344.92 & -43.80 & 19.20 & 25.91 & 339.95 & 3.77 & 0.92 \\
\hline \multirow[t]{3}{*}{ Mizunagidori } & 1 & All & 178.95 & 45.43 & 1.34 & -25.95 & 146.33 & 1.30 & 0.73 \\
\hline & 2 & $\mathrm{~T}$ & 5.18 & 2.88 & 2.60 & 53.99 & 316.46 & & \\
\hline & & $\mathrm{B}$ & 166.10 & 50.23 & 1.85 & -20.64 & 158.01 & 1.69 & 0.83 \\
\hline
\end{tabular}

G.F.R. = Goodness-fit-ratio

C.C. = Correlation coefficient.

VGP $=$ Virtual geomagnetic pole.

\subsection{Hitachi seamount}

Hitachi seamount (Figs. 6a-e) is a guyot and we modeled it as having a non-magnetized peak (Figs. 6a and b) from its crestal depth to a depth of $3200 \mathrm{~m}$. We modeled the rest of the seamount body to be normally polarized. We extended the observed bottom depth from $5800 \mathrm{~m}$ to $6200 \mathrm{~m}$ (Fig. 6b). Calculated magnetic anomalies (Fig. 6d) for Hitachi seamount resemble the observed magnetic anomalies (Fig. 6c). The resulting residual magnetic anomalies (Fig. 6e) are not significant.

Hitachi seamount yielded a G.F.R. value of 2.9 which qualify its results (Table 1) to be reliable. However a careful study of its results in comparison with those of other seamounts (Table 1), casts some doubts on their reliability. While other seamounts show declinations of about $345^{\circ}$, Hitachi seamount shows a declination of $26^{\circ}$. Hitachi seamount also shows relatively steep positive inclination which is significantly different from any of the other seamounts. As a result the VGP for Hitachi seamount is located very far to the west. We can make three possible interpretations on the results of this seamount. The first possibility is that, these paleomagnetic results are reliable and they indicate the rotational tectonics of the area upon which Hitachi seamount resides. However there is no evidence of rotation in magnetic lineations. The second possibility is that, this seamount was formed at a different time from the rest of the seamounts 

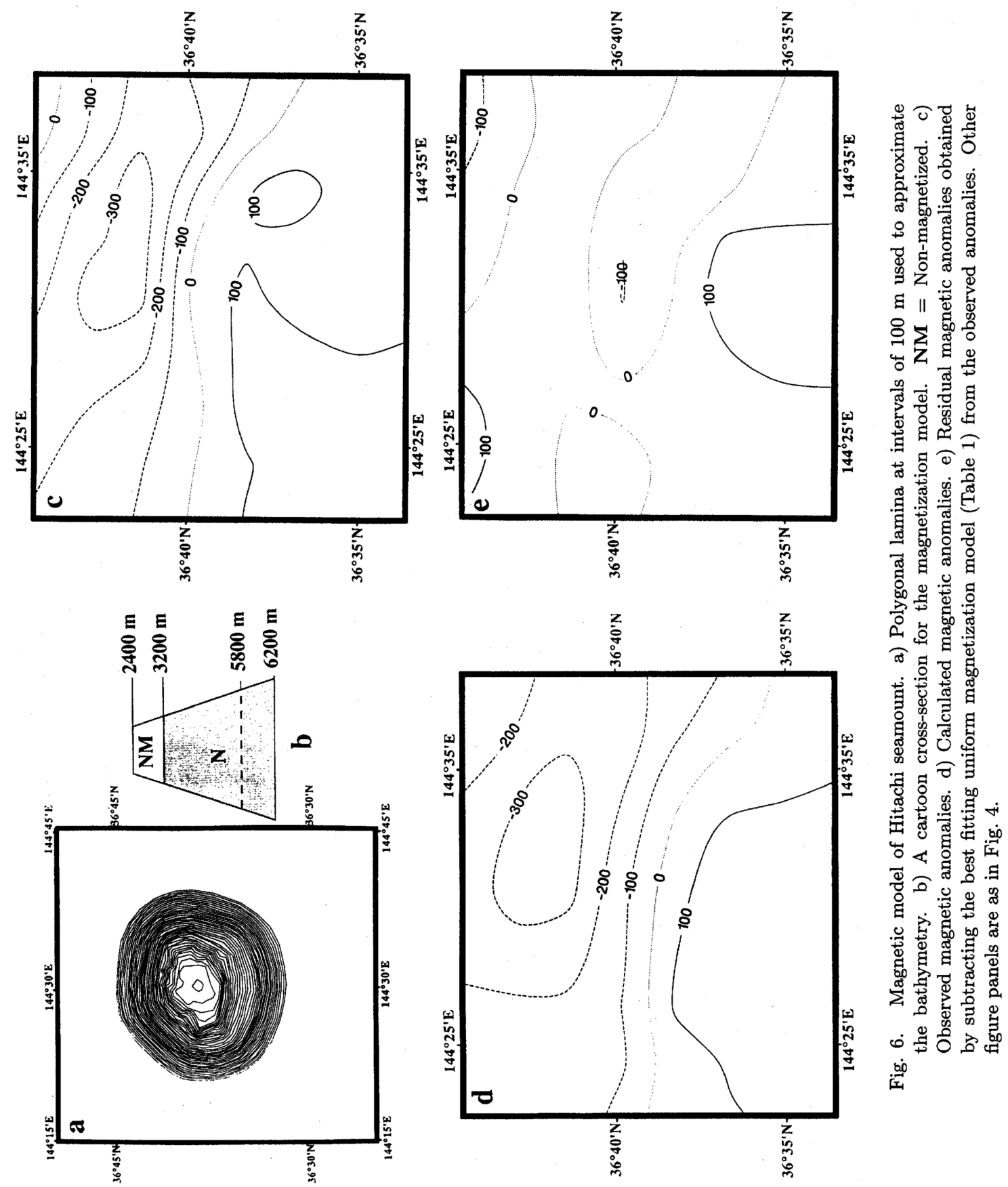
on the Joban seamount chain. The third possibility, which in our view seems to be the most probable case for this seamount, is that the significant difference of the paleomagnetic results of Hitachi seamount from those of the rest of the seamounts forming the Joban seamount chain, may be caused by interference from the magnetic field of neighboring Iwaki seamount. Iwaki seamount is the largest in size among the five seamounts on the Joban seamount chain, strongly magnetized and is located very close (about $10 \mathrm{~km}$ ) from Hitachi seamount. On the basis of these uncertainties we classify the paleomagnetic results of Hitachi seamount as "unreliable" and therefore do not attempt further interpretation of this result.

\subsection{Iwaki seamount}

The observed magnetic anomalies over Iwaki seamount (Fig. 3) are characterized by both long and short wavelength anomalies. The short wavelength magnetic anomalies necessitated the use of complex models in modelling the magnetization of this seamount. In this study we tried three different models (Figs. 7a-1) of observed magnetic anomalies over Iwaki seamount. First we modelled this seamount to have a non-magnetized peak (Figs. 7a and b) which extends from the crestal depth contour of $1700 \mathrm{~m}$ down to a depth contour of $2400 \mathrm{~m}$. We extended the observed bottom depth on this seamount from $5800 \mathrm{~m}$ to $6400 \mathrm{~m}$. The residual magnetic anomalies, (Fig. 7e) on the basis of this model which yielded a G.F.R of 2.10 (Table 1), are significant and suggest the presence of a dipolar anomaly not explained by the model. For the second model we divided the magnetized body into two blocks of magnetization (Figs. $7 \mathrm{f}$ and $\mathrm{g}$ ), i.e. the eastern block (E) and the western (W) block which comprises the main body of this seamount by taking into account the location of the residual magnetic anomalies (Fig. 7e) and the topographic shape of Iwaki seamount. The value of the G.F.R. (Table 1) increased significantly from that in the previous model to 2.90. The residual magnetic anomalies from this model (Fig. 7i) are still significant and their pattern suggests the presence of both polarities in the eastern block of magnetization. For the third model, we divided the eastern block of magnetization into two blocks of magnetization (Fig. 7j), i.e. the eastern top (ET) and the eastern bottom (EB) blocks of magnetization. The G.F.R. (Table 1) increased significantly from that in the preceding model to a value of 3.80. The residual magnetic anomalies on the basis of this model (Fig. 7l) are no longer significant, and the similarity between the observed (Fig. 7c) and the calculated (Fig. 7k) magnetic anomalies is good. This is the best of models of magnetization for Iwaki seamount we obtained in this study.

As far as the results of Iwaki seamount (Table 1) are concerned, the western block of magnetization which forms the main body of this seamount and the eastern bottom block of magnetization give declination values which are insignificantly different from each other, and from those of DainiKashima and Daisan-Kashima seamounts. This suggests that a declination of about $345^{\circ}$ may be reasonable for the seamounts forming the Joban seamount chain. The eastern top (ET) block gives a value of declination which is very different from what should be expected. Furthermore, there is a large difference between the inclination of the western block (W) and those of the two eastern blocks (ET and EB). The two eastern blocks show very steep inclinations compared to that shown by the western block. This difference in inclinations together with the unreasonable declination of the eastern top block (ET) may be accounted for as resulting from the uncertainty in the assignment of boundaries between the separate blocks of magnetization (MCNUTT, 1986).

Strictly speaking, it should be noted that the results for Iwaki seamount are not suitable for calculation of a reliable paleomagnetic pole. They are however useful in studying the magnetization structure of this seamount. Observed increase of the G.F.R. may naturally come from the increase of the degrees of freedom (number of magnetization blocks) in the model. However, increasing the degrees of freedom in the model complicates the model and makes the results unsuitable for conventional paleomagnetic purposes because of the uncertainties involved (MCNUTT, 1986). 


\subsection{Mizunagidori seamount}

Observed magnetic anomalies due to Mizunagidori seamount are partly obscured by the field of the seafloor lineations (Fig. 3). Therefore before attempting to model these anomalies we tried to remove the effect of magnetic lineations. Different methods have been used by different investigators in removing the effect of magnetic lineations. FRANCHETEAU et al. (1970), for the study of the magnetization of the Pioneer seamounts, removed the effect of magnetic lineations by joining up by hand the lineations through the seamount anomalies, and subtracting this lineated field. YAMAZAKI (1988), in the study of the magnetization of Erimo seamount, modelled the magnetic anomaly lineations using a two dimensional block model, before removing them out. In this study we apply another method in removing the effect of magnetic anomaly lineations from the observed magnetic anomalies over Mizunagidori seamount.

First we prepared two data files, file A containing all the observed magnetic anomaly data over Mizunagidori seamount survey area, and file B containing the observed magnetic anomaly data over the same area but without including data from the central part of the survey area which may contain the magnetic anomalies caused by Mizunagidori seamount. We gridded the data in these two files at an interval of $1.5 \mathrm{~km}$ and plotted them (Figs. 8a and b). Magnetic anomaly (Fig. 8b) from file $\mathrm{B}$ which should represent magnetic anomalies due to the (oceanic crust) magnetic anomaly lineations at the survey area correlates well with magnetic anomaly lineations in NAKANISHI et al., (1989). We calculated magnetic anomalies which are solely caused by Mizunagidori seamount by subtracting corresponding grid anomaly data of file B from file A and plotted them (Fig. 8c). These magnetic anomalies are the ones which we analyzed in this study, and are herein refered to as "observed" seamount magnetic anomalies.

We tried two magnetization models for Mizunagidori seamount (Figs. 8d-j). In the first model (Figs. 8d and e), we modelled Mizunagidori seamount to be uniformly magnetized in a reverse polarity. We extended the observed bottom depth for this seamount from $5800 \mathrm{~m}$ to 6300 m. A careful study of the residual magnetic anomalies map (Fig. 8g) reveals presence of two 100 $\mathrm{nT}$ residual magnetic anomalies contours that one lie to the north and the other to the south of a negative $100 \mathrm{nT}$ residual magnetic anomaly contour. Given the low values of the observed magnetic anomalies over this seamount, this configuration and values of the residual magnetic anomalies may indicate the presence of both components of polarization, i.e. normal and reverse polarities, in the magnetic anomalies of this seamount. Together with the very low value of the G.F.R., 1.3, obtained in the first model (Table 1), this warranted consideration of the second model of magnetization (Fig. $8 \mathrm{~h}$ ) for this seamount in which we divided the seamount body into two blocks of magnetization with their boundary being placed at a depth contour of $3500 \mathrm{~m}$. We modeled the top block to be normally polarized and the bottom block to be reversely polarized. The G.F.R. (Table 1) increased slightly to 1.7 by using this model.

Seamount paleomagnetic results associated with G.F.R. values below 1.8-2.0 are usually considered to be unreliable for paleomagnetic purposes (HARRISON et al., 1975; SAGER, 1983; SAger and PrIngle, 1987, 1988). Therefore results for Mizunagidori seamount (Table 1) are not reliable for paleomagnetic purposes. The declinations of both blocks of magnetization in the second model differ greatly from those of the other seamounts. The top block shows shallow inclination of $2.9^{\circ}$ which is insignificantly different from that of Daisan-Kashima seamount, while the bottom block shows very steep inclination of $50.2^{\circ}$. The poor results obtained for Mizunagidori seamount suggest this seamount may have a complex magnetization structure which is probably responsible for the apparent weak magnetization of this seamount as manifested by its small observed magnetic anomalies. This apparent weak magnetization can be accounted for by the following three possibilities.

The first possibility is that Mizunagidori seamount is truly weakly magnetized probably because this seamount is composed of rocks such as limestones which have a character of weak magnetization. Such seamounts are known to exist especially among the continental margin 

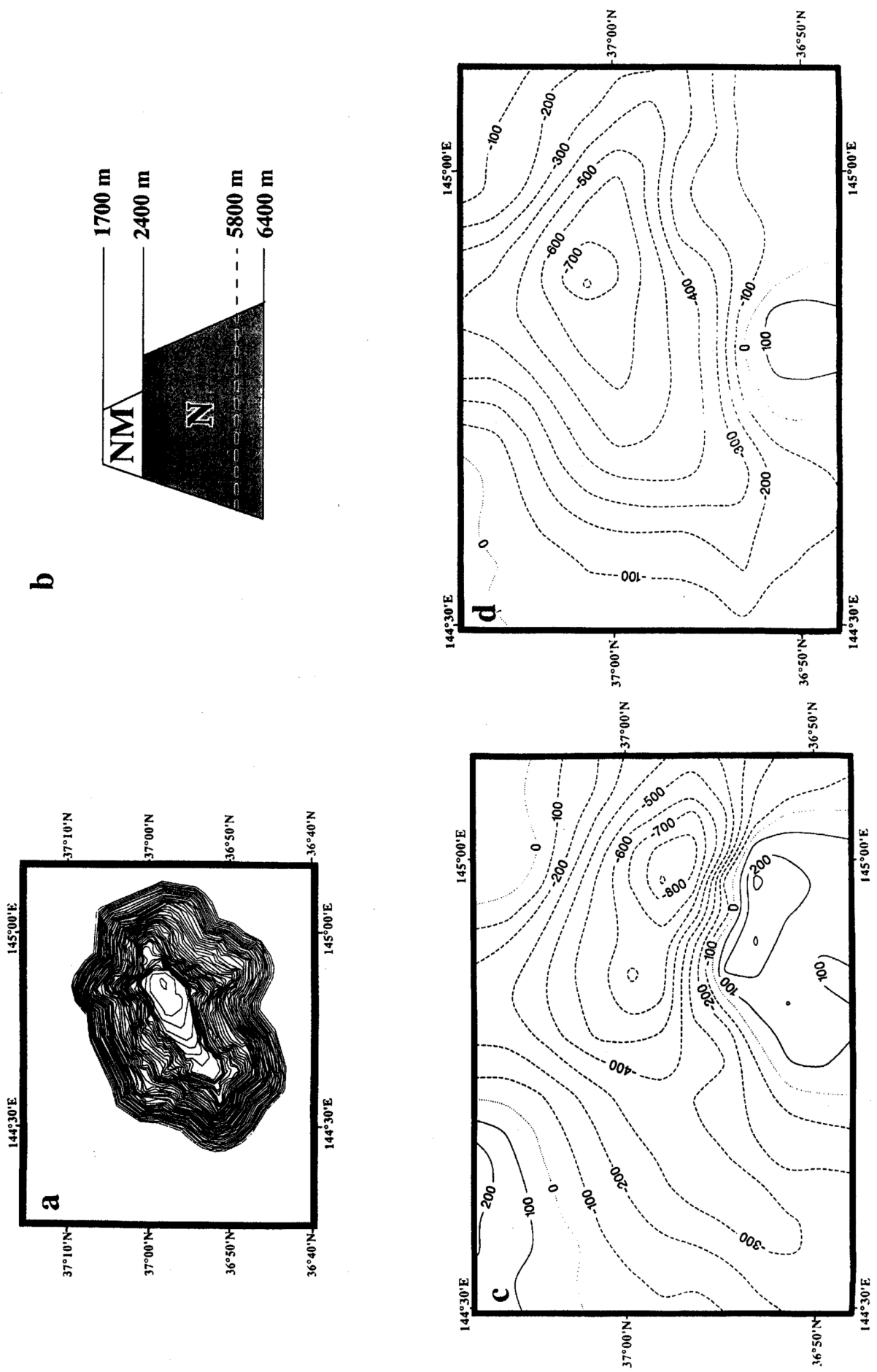


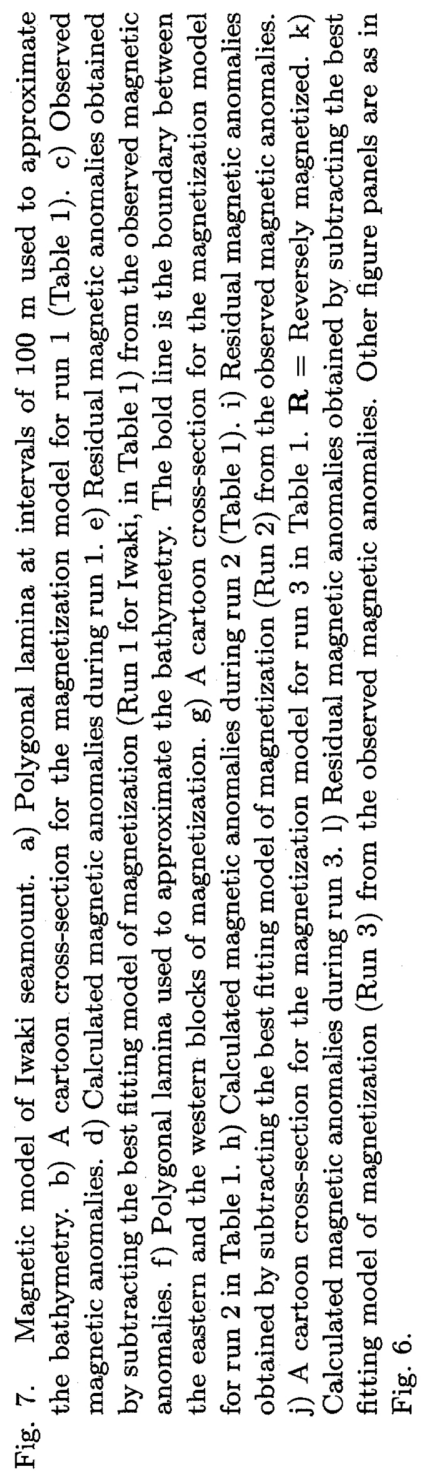



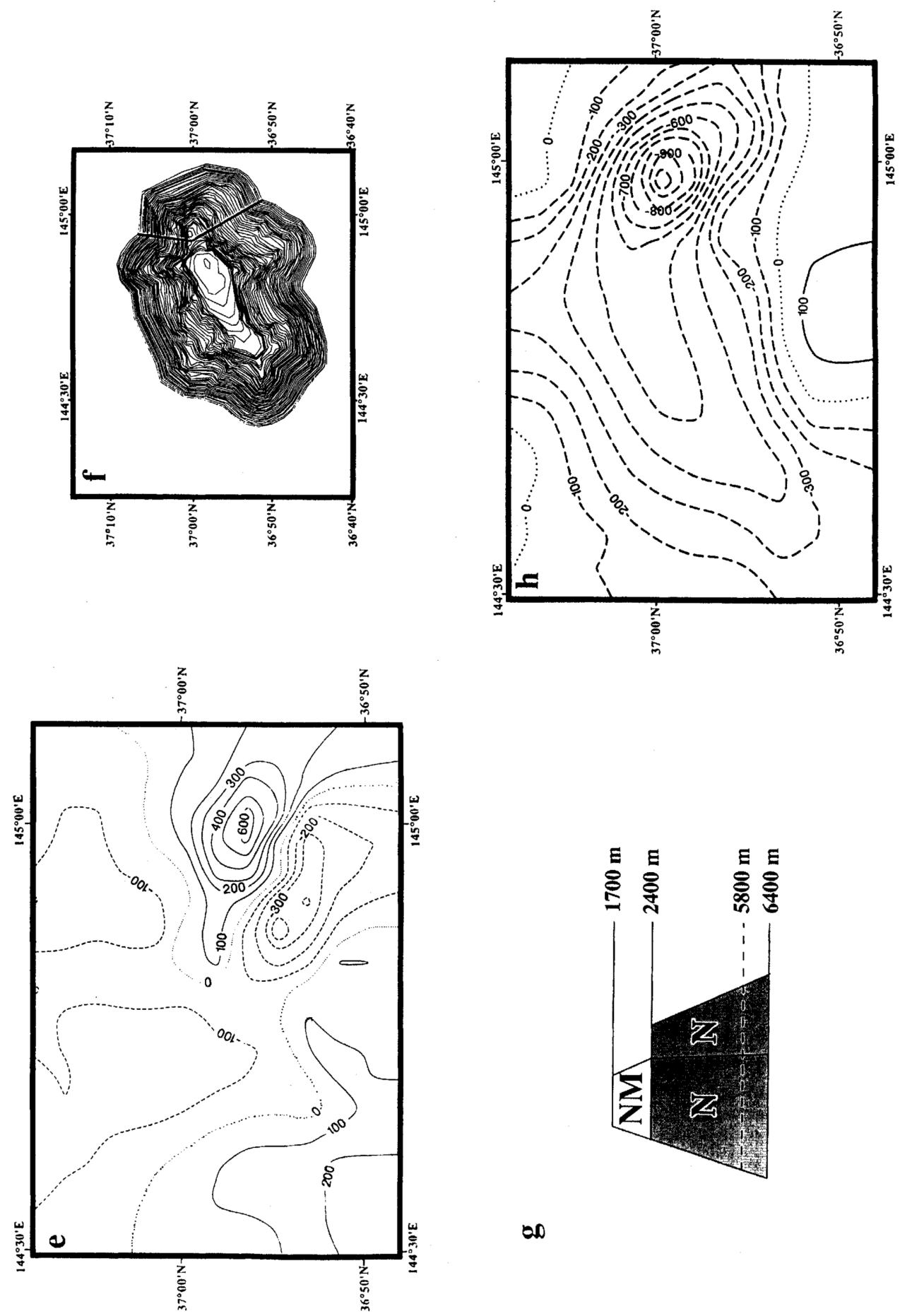

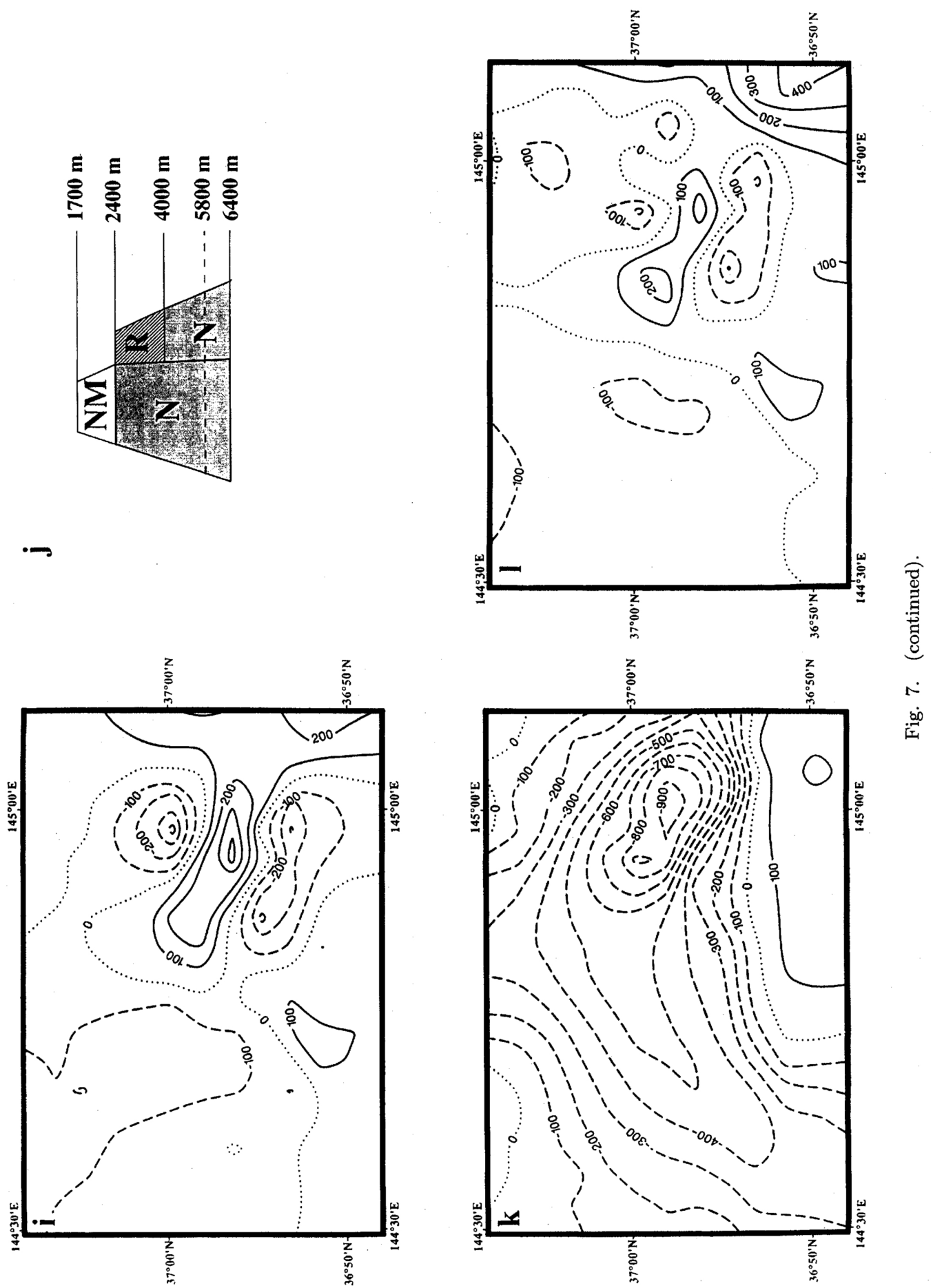

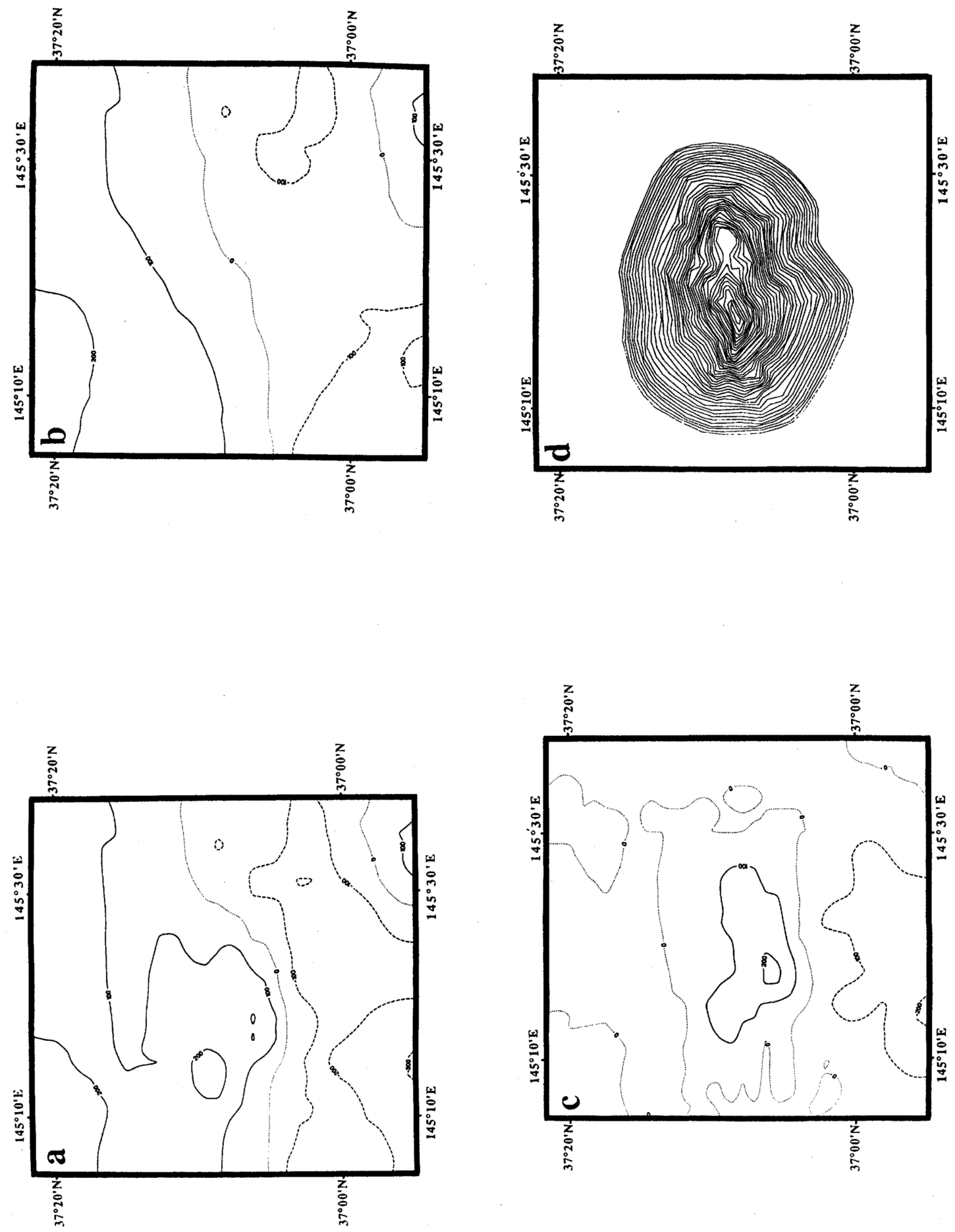


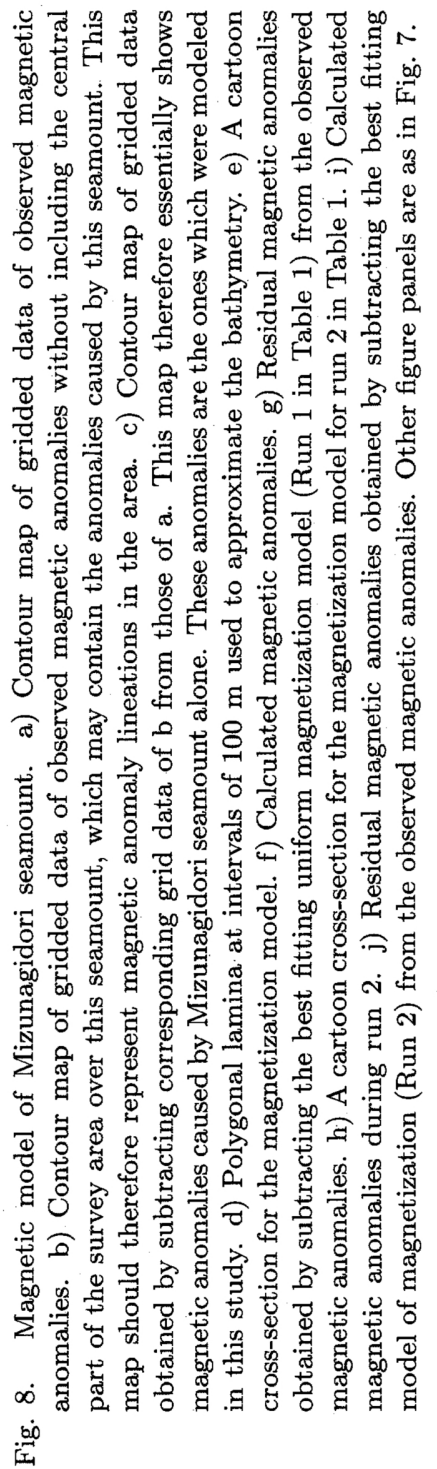



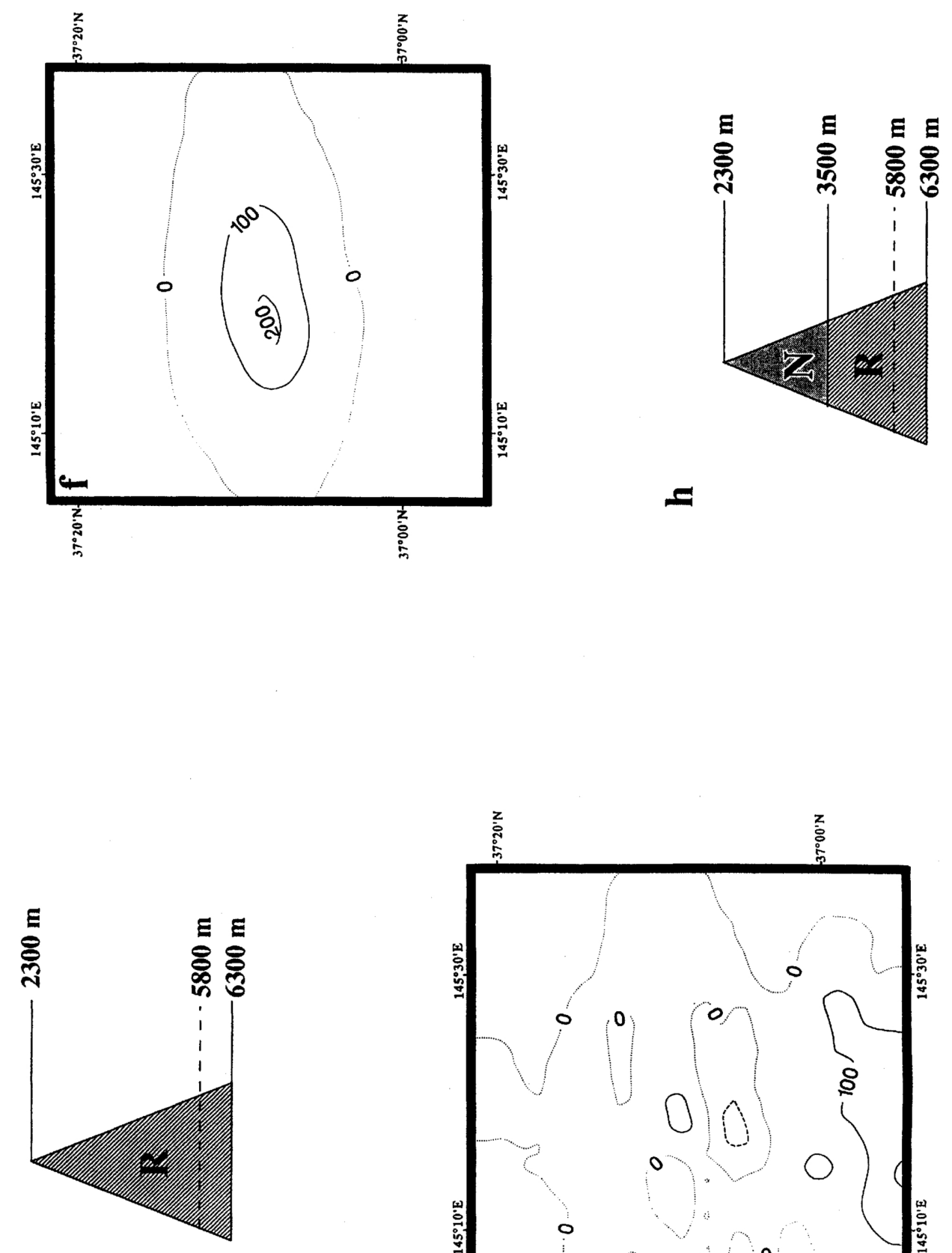

4

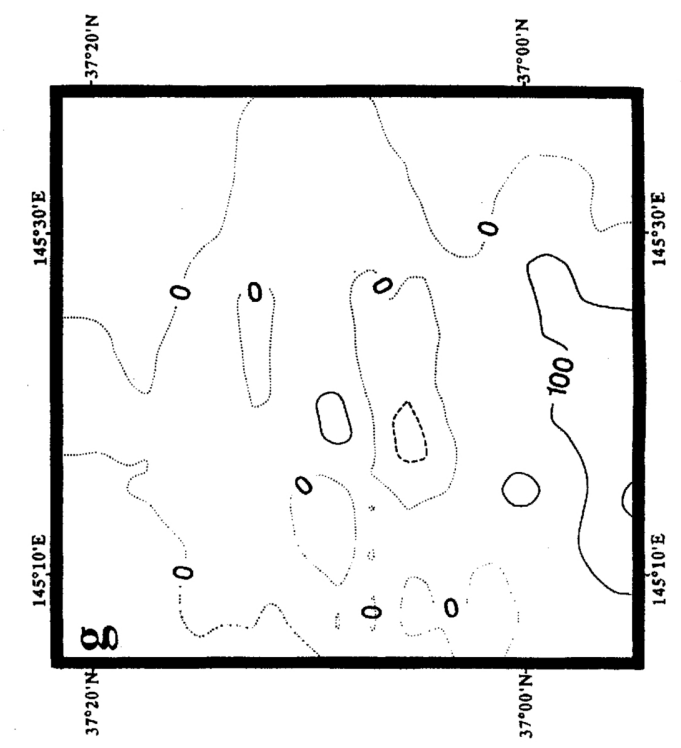



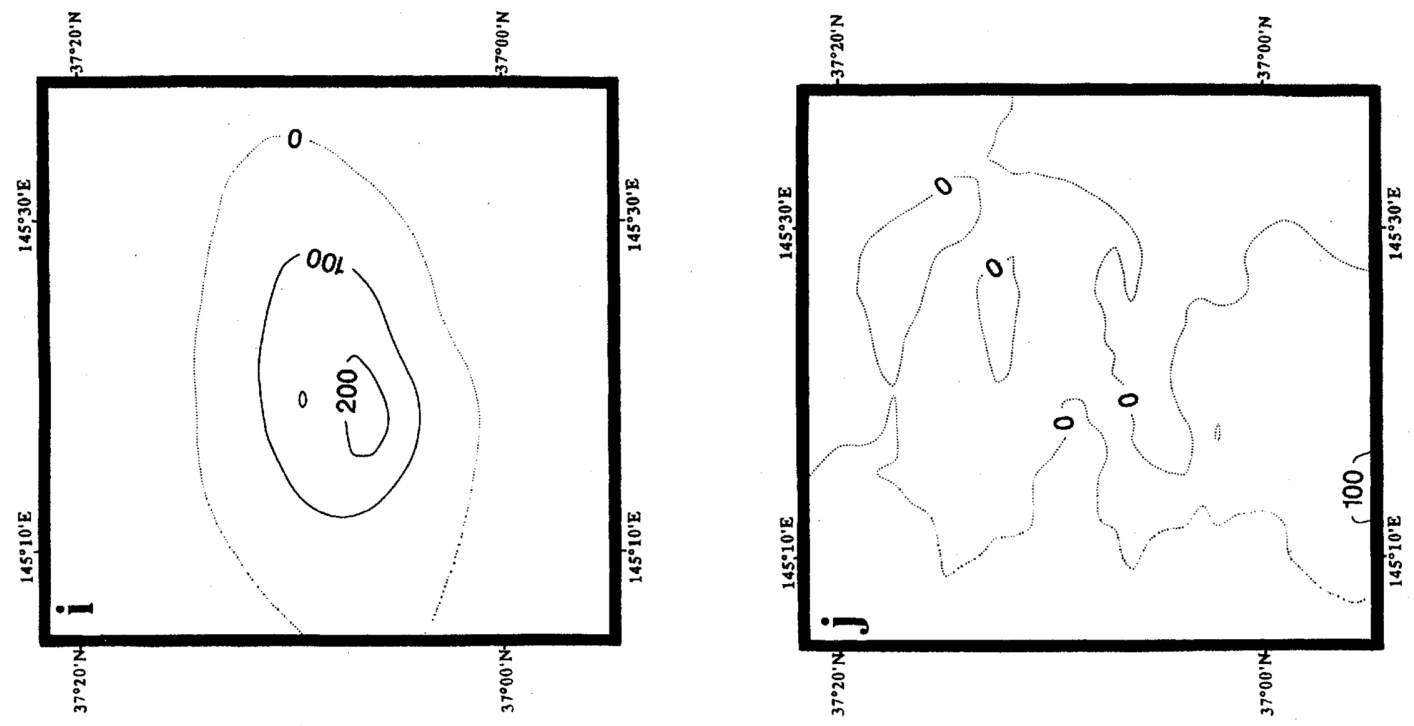
seamounts (BLACK et al., 1964). However this possibility may not be the case for Mizunagidori seamount because this seamount lies along a chain of seamounts that are clearly volcanic in origin. The second possibility is based on the work of VerHOEF and ARKANI-HAMED (1990) in which they presented a model which shows that the thermal remanent magnetization (TRM) decays exponentially with time while the chemical remanent magnetization (CRM) increases exponentially at the same rate. According to their model, magnetic anomalies which were formed during the reverse polarity at $\mathrm{M} 0$, will be erased because this polarity was followed by a longer normal polarity. However, by the fact that we still observe magnetic anomaly lineations of M0 age which are often very clear in the world oceans, this possibility is not very convincing. The third possibility, which in our view seems to be the most probable case, is that the magnetization structure of Mizunagidori seamount is composed of multi-polarity reversals (MASALU et al., 1991a, 1991b; MASALU, 1991). In such a situation the multi-polarity reversals tend to cancel out and the magnetic anomaly we observe is the resultant of this cancellation. It is known for instance that the effect of the presence of multi-polarity magnetization in modelling magnetic anomalies of a seamount, is to give an apparently weak magnetization intensity if uniform magnetization is assumed (MCNUTT, 1986; PRINGLE et al., 1991). The intensity of magnetization of Mizunagidori seamount increased when a two layer model was assumed. We therefore suggest that observed magnetic anomalies over Mizunagidori seamount may be affected in the same manner by the presence of multi-polarity magnetization of this seamount.

\section{Discussion}

The resolution of our paleomagnetic results for the seamounts forming the Joban seamount chain and the fact that none of these seamounts is reliably dated, does not allow an unequivocal conclusion on the origin of the Joban seamount chain. We estimated the ages of the seamounts forming the Joban seamount chain by comparing the reliable seamount paleomagnetic poles with the known Pacific plate Apparent Polar Wander Path, and by backtracking the crestal depth of guyot seamounts to sea surface. We checked concurrently the appropriateness of our models of magnetization and age estimations for the seamounts by comparing the expected and calculated paleomagnetic parameters for each seamount.

\subsection{Comparison with the known Pacific plate apparent polar wander path}

If a reliable VGP of a seamount is known, it can be used in either of the following two ways. Firstly, if the seamount is reliably dated this VGP can be used to refine the known APWP (Apparent Polar Wander Path) of the plate concerned. Secondly, if the seamount is not dated this VGP can be compared with the known APWP of the plate concerned to estimate the age of the seamount (MCNutT, 1986; SAGER and PRINGle, 1987, 1988, 1990; SAGER, 1992).

In the case of this study only one seamount, Daini-Kashima seamount, has been previously dated (KANEOKA, 1971), but that date, which was obtained by the K-Ar method, is probably unreliable, because K-Ar dates from submarine basalts are notoriously biased by Ar loss, as result of which dates are under estimated. However results from two seamounts (Table 1), DainiKashima and Daisan-Kashima seamounts, appear to be reliable on the basis of their high G.F.R.s and good qualification on the basis of the other goodness test parameters and factors described in chapters 3 and 4. We compared the VGPs of these two seamounts (Fig. 9) with the known Pacific APWP (SAger and Pringle, 1988) and found that they lie slightly south of the Pacific APWP near the $82 \mathrm{Ma}$ pole. Their location suggests that the age of Daini-Kashima and DaisanKashima seamounts is about $82 \mathrm{Ma}$ which is surprisingly consistent with the K-Ar date of 81 Ma (KANEOKA, 1971) proposed for Daini-Kashima seamount. This suggests that this date may be nearly correct for Daini-Kashima seamount. The closeness of the two VGPs suggests that Daini-Kashima and Daisan-Kashima seamounts may have about the same age. 


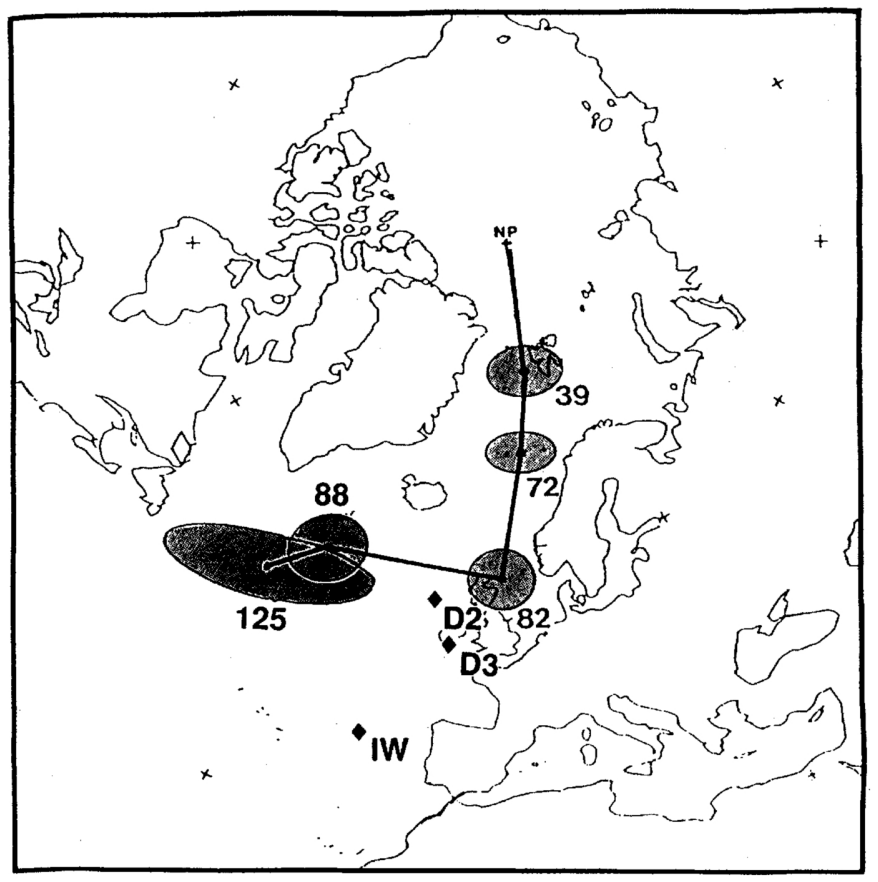

Fig. 9. Comparison of the VGPs of Daini-Kashima (solid diamond marked D2), Daisan-Kashima (solid diamond marked D3) and Iwaki (solid diamond marked IW) seamounts with the known Pacific APWP. Large dots are pole positions of the Pacific APWP surrounded by $95 \%$ confidence regions (shaded) (SAGER and PRINGLE, 1988; Gordon, 1990). Large numbers are the mean age of the poles.

\subsection{Age estimation for guyot seamounts}

Two of the seamounts in this study, Iwaki and Hitachi seamounts, are guyots. A flat top of a seamount is one of the geomorphic features which are usually thought to originate at or near sea level (TUCHOLKE and SMOот, 1990). Bevelling of seamount crests at wave base, which is often accompanied by reef growth, is a well documented phenomenon in the Pacific (e.g., HAMILTON, 1956; SCHLANGER et al., 1987; WINTERER et al., 1992; VAN WAASBERGEN and WINTERER, 1992; LINCOLN et al., 1992). If we know the present depths of these features, the age of the underlying crust and the relevant crustal age-depth relationship, we can backtrack the features from their present depth to derive the times when they were at or near sea level, and thus the approximate age of their formation as successfully done by TUCHOLKE and SMOOT (1990) to present evidence for age progression and evolution of Corner seamounts and Great Meteor Seamount Chain in the Northern Atlantic, from multibeam bathymetry. However, this method should be used with some caution. Age estimates obtained by this method should be regarded as minimum estimates because during volcanism, the thermal age of the lithosphere may most probably reset to some extent. This means shorter period of time is needed for subsiding to the same depth, and thus age estimates should become younger. Caution should also be taken when the area concerned is near to a trench, in which case bending of the lithosphere may affect the depth of the seamounts.

As far as this study is concerned, because the Joban seamount chain lies on the Northwestern Pacific, we used the crustal age-depth relationship curve of the North Pacific of PARSONS and SCLATER (1977). We obtained ages of the crust upon which Iwaki and Hitachi seamounts reside from NAKANISHI et al. (1989). Observed ocean floor depth around these seamounts is about $5800 \mathrm{~m}$. Based on the age-depth relationship curve we used and the age of the crust, expected 
ocean floor depth around these seamounts is $6030 \mathrm{~m}$. Taking into account the sediment thickness, the difference between observed and expected ocean floor depths suggest that both age resetting and bending of the lithosphere on the study area may be minimal, and hence will not affect our results very much.

After backtracking the crestal depth $(1700 \mathrm{~m})$ of Iwaki seamount (Fig. 10), we found that it was at or near the sea level when the age of the crust was about $25 \mathrm{My}$. Because the present age of the crust on which this seamount lies is about $136 \mathrm{Ma}$, we obtained an the age of about 111 Ma for Iwaki seamount. We also obtained an age of about $127 \mathrm{Ma}$ for Hitachi seamount by the same method.

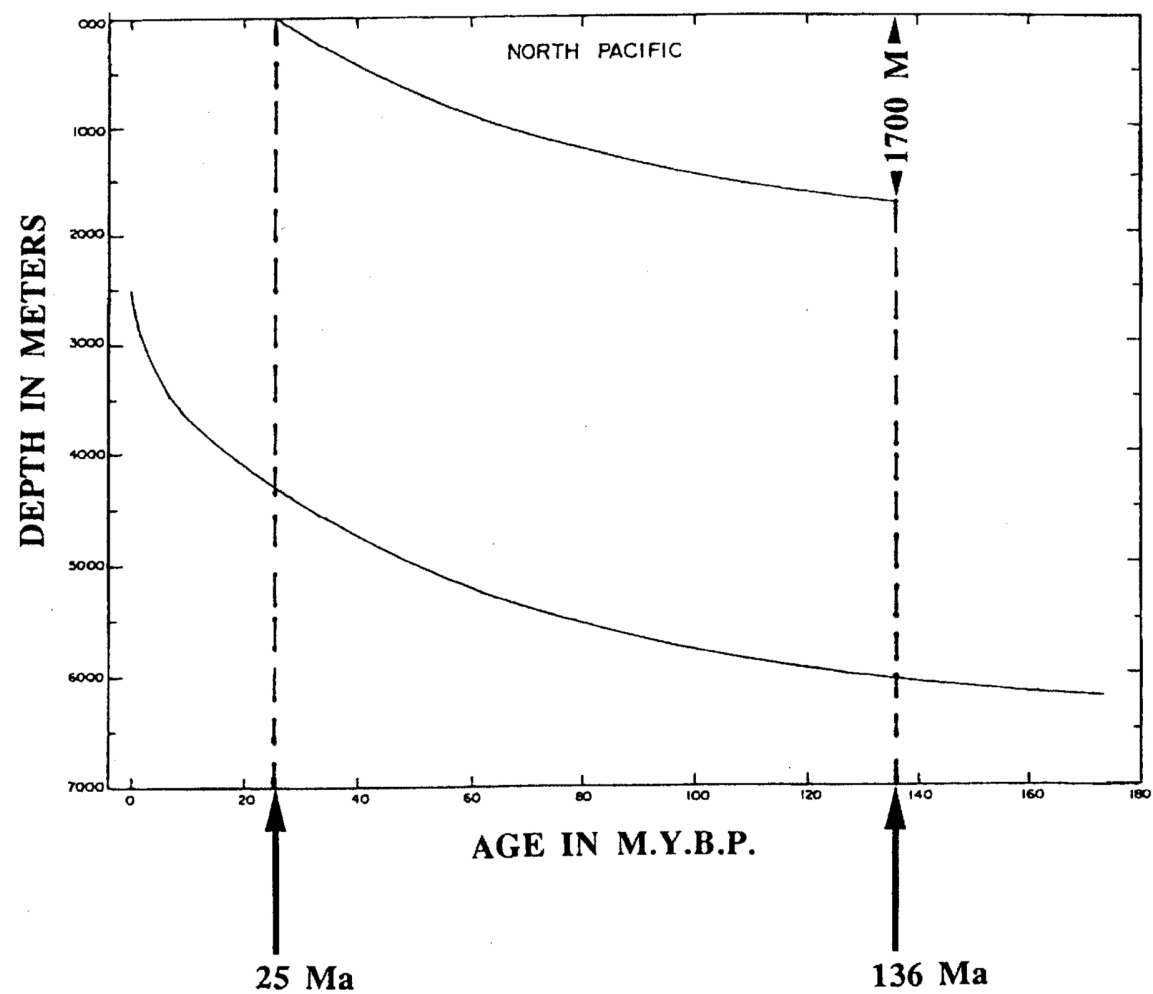

Fig. 10. Summary of age estimation for Iwaki seamount by backtracking its crestal depth along the North Pacific crustal age-depth relationship curve to sea level. The crestal depth of Iwaki seamount (guyot) is $1700 \mathrm{~m}$. The present age of the oceanfloor on which this seamount lies is ca $136 \mathrm{Ma}$. The age of this oceanfloor when the crest of Iwaki was at or near sea level is ca $25 \mathrm{Ma}$. The age of Iwaki seamount which is simply the difference between the two ages of the oceanfloor is ca $111 \mathrm{Ma}$.

We used both the age estimations for the guyot seamounts, Iwaki and Hitachi seamounts, and for Daini-Kashima and Daisan-Kashima seamounts (in the previous section) in computing expected paleomagnetic parameters for the each seamount in the next section. We used the expected paleomagnetic parameters for checking whether our models of magnetization for the respective seamounts are 'right' and the age estimations are appropriate. 


\subsection{Calculated versus expected paleomagnetic parameters}

If the age of a seamount and the motion of the plate upon which it resides are well constrained, expected paleomagnetic parameters of declination and inclination for the seamount can be computed by backtracking the seamount to its paleoposition of formation. These parameters can then be used to choose the "right" model of magnetization for this seamount (MCNUTT, 1986). Published paleomagnetic results of seamounts in some cases disagree significantly with those predicted from models of absolute plate motion. A good example to show this is paleomagnetic results for Erimo seamount (Table 2) that has been obtained by three different workers (UYEDA and Richards, 1966; Hildebrand and PARKER, 1987; YAMAZAKI, 1988). Erimo seamount has been estimated to be $100-120 \mathrm{Ma}$ by ${ }^{40} \mathrm{Ar}-{ }^{39} \mathrm{Ar}$ method (TAKIGAMI et al., 1989) and by analysis of the elastic thickness of the plate at the time of emplacement of the seamount using free-air gravity anomalies (CADET et al., 1987). On the basis of the estimated age for Erimo seamount and the motion of the Pacific plate according to DUNCAN and ClaGUE (1985), expected declination and inclination for Erimo seamount are between $1.3^{\circ} \mathrm{E}$ to $1.58^{\circ} \mathrm{E}$ and $-8.83^{\circ}$ to $-3.5^{\circ}$ respectively (Table 2). Only the calculated declination value of $1^{\circ} \mathrm{E}$ obtained by YAMAZAKI (1988) is nearly consistent with expected parameters. The rest of the calculated declination values (Table 2) range between $334^{\circ} \mathrm{E}$ to $342.4^{\circ} \mathrm{E}$ with an average of about $339.25^{\circ} \mathrm{E}$. Calculated inclination values for Erimo seamount (Table 2) range between $22^{\circ}$ to $38^{\circ}$ with an average of about $30.56^{\circ}$.

Table 2. Calculated versus expected paleomagnetic parameters for Erimo seamount.

\begin{tabular}{|c|c|c|c|c|}
\hline \multirow[b]{2}{*}{ Age $(\mathrm{Ma})$} & & \multicolumn{2}{|c|}{ Paleomagnetic Parameters } & \multirow[b]{2}{*}{ Source } \\
\hline & & Dec. & Inc. & \\
\hline $100-120$ & Expected & 1.58 to 1.31 & -3.50 to -8.83 & DUNCLA \\
\hline$\prime \prime$ & Calculated & 1.00 & 36.0 & 1 \\
\hline$\prime \prime$ & " & 334.00 & 29.0 & 1 \\
\hline " & " & 341.00 & 22.0 & 2 \\
\hline$\prime \prime$ & "1 & 342.40 & 27.9 & 3 \\
\hline " & " & 339.60 & 37.9 & 4 \\
\hline $\begin{array}{l}1=\mathrm{YA} \\
2=\mathrm{UY} \\
3=\mathrm{HI} \\
4=\mathrm{HI} \\
\text { DUNC }\end{array}$ & $\begin{array}{l}\text { MAZAKI }(198 \\
\text { DEB and RIC } \\
\text { DEBRAND an } \\
A=\text { DUNCA }\end{array}$ & $\begin{array}{l}\text { IARDS (1966). } \\
\text { A PARKER (19) } \\
\text { PARKER (19. } \\
\text { N and ClAGUE }\end{array}$ & $\begin{array}{l}\text { 7). } \\
\text { 7)-Seminorm n } \\
\text { (1985) model. }\end{array}$ & ethod. \\
\hline
\end{tabular}

It has been known for many years that predicted and observed Pacific APWP diverge before about $80 \mathrm{Ma}$. Various hypotheses have been proposed to explain this discrepancy. These are: true polar wander (GORDON, 1983), poorly defined hotspot motion of the Pacific plate prior to 80 Ma (SAGER and PRINGLE, 1988), and an unrecognized Early Cretaceous rotation (JARRARD and SASAJIMA, 1980). Therefore the usefulness of the method of comparing calculated and predicted paleomagnetic parameters for a seamount may depend on the age of the seamount. For this study, two seamounts that yielded reliable results, Daini-Kashima and Daisan-Kashima seamounts, have been estimated to have ages in the range of 80 to $90 \mathrm{Ma}$. This age estimate is close to the time at which observed and predicted polar wander paths diverge (SAGER and PRINGLE, 1988). However, the two guyots, Hitachi and Iwaki seamounts, have been estimated to be older (110 to $130 \mathrm{Ma}$ ) than this divergence. Therefore we expect that calculated and predicted paleomagnetic 
parameters for Daini-Kashima and Daisan-Kashima seamounts should be consistent, whereas the calculated and predicted paleomagnetic parameters for Hitachi and Iwaki seamounts should show a large degree of inconsistency. By comparing the calculated and predicted paleomagnetic parameters for Daini-Kashima and Daisan-Kashima seamounts, and those for Hitachi and Iwaki seamounts we should be able to deduce information about the discrepancy between observed and predicted Pacific APWP.

Firstly, we tested the calculated paleomagnetic parameters for the seamounts that yielded reliable results by comparing them with the expected paleomagnetic parameters predicted by models of absolute plate motion of the Pacific plate. The absolute motion of the Pacific plate has been studied extensively (e.g., Henderson, 1985; Engebretson et al., 1985; Duncan and Clague, 1985). These models of absolute motion of the Pacific plate are based on hotspot tracks. We computed the expected paleomagnetic parameters based on the model of DUNCAN and Clague (1985) and the ages of seamounts we estimated above. This method enables us to check whether our paleomagnetic results represent the "right" models of magnetization for the respective seamounts, and at the same time to check whether our age estimations for the respective seamounts are appropriate.

Table 3 summarizes the comparison between the calculated versus expected paleomagnetic parameters for the seamounts that yielded reliable results. Calculated inclination for one seamount, Daisan-Kashima seamount, is coincident with the expected range values. Calculated inclination for Daini-Kashima falls slightly out of the expected range suggesting that this seamount may be slightly younger than the lower limit of the estimated age range. In general, however, this inclination appears to be close to appropriate for this seamount. Calculated declinations for the two seamounts are insignificantly different from each other and show a counterclockwise rotation of about $15^{\circ}$ of the Pacific plate. These parameters are inconsistent with their expected range that suggests a clockwise rotation of the Pacific plate of only about $4^{\circ}$. However, the fact that calculated declinations are insignificantly different from each other (Table 3 and Table 1) may indicate that these declinations are reasonable and appropriate. Moreover, these two paleopoles lie within the distribution of other seamount paleomagnetic poles along the polar wander path.

Table 3. Calculated versus expected paleomagnetic parameters.

\begin{tabular}{lccccr}
\hline Seamount & Estimated & \multicolumn{4}{c}{ Paleomagnetic parameters } \\
& Age (Ma) & \multicolumn{2}{c}{ Calculated } & \multicolumn{2}{c}{$\begin{array}{c}\text { Expected } \\
\end{array}$} \\
& & Dec. & \multicolumn{1}{c}{ Inc. } & Dec. & \multicolumn{1}{c}{ Inc. } \\
\hline Daini-Kashima & $80-90$ & 345.74 & 7.77 & 2.89 to 3.41 & 6.24 to -3.03 \\
Daisan-Kashima & $80-90$ & 342.76 & 3.28 & 3.50 to 3.94 & 6.51 to -2.76 \\
Iwaki (W) & $110-130$ & 346.68 & -14.77 & 2.45 to 1.75 & -10.27 to -9.23 \\
\hline
\end{tabular}

Secondly, we applied the same test to the results of Iwaki seamount and found that the results of the western block of magnetization, Iwaki (W), which forms the main body of seamount appear to be reasonable (Table 3). As in the case of Daini-Kashima seamount, the calculated inclination for Iwaki (W) falls slightly out of the expected range. Calculated declination for Iwaki (W) is insignificantly different from those of Daini-Kashima and Daisan-Kashima seamounts. However, Iwaki seamount is much older than both Daini-Kashima and Daisan-Kashima seamounts, so the declinations should be different according to the Pacific apparent polar wander path. Moreover, the VGP for Iwaki (W) (Fig. 9) does not agree with the Pacific polar wander path; it falls to the south, well outside the population of other seamount paleomagnetic poles. This indicates 
that our Iwaki (W) results do not have a reliable declination. Assuming that to be the case, paleomagnetic results from the Joban seamount chain suggests that there existed a rotation of plate between $130 \mathrm{Ma}$ and $90 \mathrm{Ma}$. This is consistent with the hypothesis of an unrecognized Mid-Cretaceous rotation (JARRARD and SASAJIMA, 1980). The three VGPs, for Daini-Kashima, Daisan-Kashima and Iwaki (W) seamounts, lie in the Mid Cretaceous period (80-120 Ma) on the Pacific APWP. This period may represent the age of formation of the Joban seamount chain.

Paleomagnetic results for Daini-Kashima, Daisan-Kashima and Iwaki (W) seamounts (Table 3) show consistency between calculated and expected inclinations. However, these results show large discrepancy between calculated and expected declinations. Because calculated declinations for Daini-Kashima and Daisan-Kashima seamounts are insignificantly different from each other, the discrepancy shown is due to poorly constrained rotation of the Pacific plate prior to 80 Ma. This discrepancy may be accounted for by two hypotheses: an unrecognized Mid Cretaceous rotation (JARRARD and SASAJIMA, 1980), and poorly defined models of plate motion relative to hotspots prior to $80 \mathrm{Ma}$ (SAGER and PRINGLE, 1988).

\subsection{The origin of the Joban seamount chain}

The Joban seamount chain trends along $\mathrm{N} 53^{\circ} \mathrm{E}$ which is inconsistent with any of the previous models (e.g., Henderson, 1985; Engebretson et al., 1985; DunCan and Clague, 1985) of motion of the early Mesozoic Pacific plate. The possibility of formation of the Joban seamount chain on a spreading center is straightforwardly ruled out from the fact that the chain trends oblique to the $\mathrm{N} 68^{\circ} \mathrm{E}$ trend of the magnetic anomaly lineations of the surrounding ocean-floor (Kobayashi, 1991; MASAlu et al., 1991a, 1991b; Masalu, 1991).

From the previous section, the fact that calculated inclination for Iwaki (W) seamount is significantly different from calculated inclinations for Daini-Kashima and Daisan-Kashima seamounts, suggests the presence of at least two groups of inclinations, in the range of $3^{\circ}$ to $8^{\circ}$ and $-15^{\circ}$ to $-9^{\circ}$, within the Joban seamount Chain. These groups of inclinations suggest the presence of at least two groups of seamounts that were formed at significantly different paleolatitudes. From this we conclude that the formation of the Joban seamount chain was not due to the passage of the Pacific plate over a single stationary hotspot.

The paleomagnetic results obtained in this study are generally consistent with two hypotheses that attempt to explain the origin of the intraplate volcanism in the western Pacific. The first hypothesis presumes that western Pacific volcanoes were formed as the western Pacific passed over a congregation of hotspots currently located in the southeast Pacific (HENDERSON and GoRDON, 1981; HENDERSON, 1985; MCNUTT and FisCHER, 1987). The other hypothesis attempts to explain the origin of intraplate seamounts by one or more widespread pulses of voluminous volcanism (MENARD, 1964, 1984). Evidences have been found by other investigators that imply widespread volcanic episodes occurred during the Mid-Cretaceous, Late-Cretaceous, and Eocene (Schlanger et al., 1981; Schlanger and Premoli-Silva, 1981; Haggerty et al., 1982; ReA and VALLIER, 1983). From the data available and the present results, we can not disprove or confirm either hypothesis, the hotspot or widespread volcanic pulse mechanisms, for the origins of the seamounts forming the Joban seamount chain.

Another possible mechanism of origin for the Joban seamount chain or a part of the chain may be volcanism along a pre-existing weak zone in the crust such as a rupture of the oceanic plate. Rupture of the lithosphere may have been caused by tensions which were probably developed in it during Mid-Cretaceous unrecognized rotation of the Pacific plate (JARRARD and SASAJIMA, 1980). This idea may be supported by two observations. Firstly, Iwaki seamount, the largest seamount on the Joban seamount chain, is elongated along the trend of this seamount chain. Secondly, Iwaki and Hitachi seamounts are connected at depth contours greater than $3600 \mathrm{~m}$. Elongation of crestal portions of Iwaki and Mizunagidori seamounts apparently along the magnetic lineations of surrounding crust seems to indicate that primary fracture along the spreading fabric 
of the ocean-floor is also associated with the secondary rupture. A similar origin of a seamount chain has been proposed for the formation of some seamounts on the Line Islands chain in the central Pacific, by the rupturing of the lithosphere due to tensions that were probably developed in it when the Pacific plate changed its drifting direction at about $43 \mathrm{Ma}$ (SAGER and KEATING, 1984).

\section{Conclusions}

We performed inversion analyses to five seamounts on the Joban seamount chain resulting in well constrained magnetization structures of three seamounts. Daini-Kashima, DaisanKashima and Hitachi seamounts are solely normally polarized. The paleomagnetic results for Hitachi seamount appear to have been affected by interference from magnetic field of the nearby Iwaki seamount. The magnetization structure of Iwaki seamount shows a complex magnetization structure with the presence of both vertical and lateral inhomogeneities of magnetization. The magnetic anomaly intensity of Mizunagidori seamount appears to be weakened by probably multi-polarity reversal magnetization of this seamount.

The virtual geomagnetic poles for Daini-Kashima, Daisan-Kashima and Iwaki (W) seamounts lie along the Mid to Late Cretaceous Pacific plate apparent polar wander path. This period may represent the age of formation of the Joban seamount chain. We estimated Daini-Kashima and Daisan-Kashima seamounts to have ages in the range of 80-90 Ma by comparing their VGPs with the known Pacific APWP. The VGPs for these seamounts lie slightly south of the Pacific APWP near the $82 \mathrm{Ma}$ pole consistent with the K-Ar date of $81 \mathrm{Ma}$ for Daini-Kashima seamount. Calculated inclinations for these seamounts are consinstent with their expected inclinations, computed based on models of absolute motion of the Pacific plate and estimated ages for the seamounts. We also estimated Iwaki seamount to have an age in the range of 110-130 Ma by backtracking its crest as well as the crest of Hitachi seamount along the crustal age-depth curve of the north Pacific to sea level.

The Joban seamount chain apparently shows presence of at least two groups of inclinations. This suggests that its origin is not the passage of the Pacific plate over a single stationary hotspot. However, the actual origin of the Joban seamount chain is still uncertain.

We thank the Captain and Crew staffs of the R/V Hakuho Maru of the Ocean Research Institute (University of Tokyo) and the scientific party aboard cruise KH90-1 Leg 1 during which we collected the data used in this study. Drs. A. Oshida and M. Nakanishi helped in the operation of the SeaBeam and Proton Magnetometer systems during Leg 1 of cruise KH90-1. Prof. N. Isezaki of Chiba University kindly provided us with his seamount modelling programs we used in the analyses presented in this work. Prof. W. W. Sager of Taxes A\&M university (USA), Prof. Y. Ogawa of Kyushu university (Japan) and Dr. T. Yamazaki of the Geological Survey of Japan have been very helpful to the first author for their various suggestions, discussions and continual encouragement throughout this study. We sincerely appreciate for the various stimulating discussions and continual encouragement accorded to us by post-graduate students and other staffs of the Ocean-Floor Geotectonics section of the Ocean Research Institute (the University of Tokyo). We thank W. W. Sager and an anonymous reviewer for critical and constructive reviews. The University of Dar-Es-Salaam (Tanzania) granted study leave to the first author. Finally but not least, the first author would like to express his special thanks and gratitude to the Ministry of Education, Science and Culture (MONBUSHO) of Japan, for sponsoring his study in Japan.

\section{REFERENCES}

Black, M., M. N. Hill, A. S. Laughton, and D. H. Matthews, Three non magnetic seamounts off the Iberian Coast, Quart. J. Geol. Soc. Lond., 120, 477-517, 1964. 
Cadet, J. P., K. Kobayashi, J. Aubouin, J. Boulegue, C. Deplus, J. Dubois, R. von Huene, L. Jolivet, T. Kanazawa, J. Kasahara, K. Koizumi, S. Lallemand, Y. Nakamura, G. Pautot, K. Suyehiro, S. Tani, H. TokuYama and T. Yamazaki, The Japan Trench and its juncture with the Kurile Trench: Cruise results of the Kaiko project, Leg 3, Earth and Planet. Sci. Lett., 83, 267-284, 1987.

Chart Number 1009 (Tohoku), Hydrographic Department, Maritime Safety Agency of Japan.

Chart Number 6312 (Tohoku), Hydrographic Department, Maritime Safety Agency of Japan.

Cox, A. and R. G. Gordon, Paleolatitudes determined from paleomagnetic data from vertical cores, Rev. Geophys. Space Phys., 22, 47-72, 1984.

Crough, S. T., Hotspot epierogeny, Tectonophys., 61, 321-333, 1979.

Duncan, R. A., Hotspots in the southern oceans-an absolute frame of reference for motion of the Gondwana continents, Tectonophys., 74, 29-42, 1981.

Duncan, R. A., Age progressive volcanism in the New England seamounts and the opening of the Central Atlantic Ocean, J. Geophys. Res., 89, 9980-9990, 1984.

Duncan, R. A. and D. A. Clague, Pacific plate motion recorded by linear volcanic chains, in The Ocean Basins and Margins, vol. 7A, edited by A. E. M. Nairn, F. G. Stehli, and S. Uyeda, pp. 89-121, Plenum Publishing, New York, 1985.

EmiliA, D. A. and R. L. MASSEY, Magnetization estimation for nonuniformly magnetized seamounts, Geophysics, 39, 223-231, 1974.

Engebretson, D. C., A. Cox, and R. G. Gordon, Relative motions between oceanic and continental plates in the Pacific basin, GSA Special paper / Geological Society of America; 206, 3300 Penrose Place, P. O. Box 9140, Boulder, Colorado 80301, 1985.

Fleitout, L. and C. Moriceau, Short-wavelength geoid, bathymetry and the convective pattern beneath the Pacific Ocean, Geophys. J. Int., 110, 6-28, 1992.

Francheteau, J., C. G. A. Harrison, J. G. Sclater, and M. L. Richards, Magnetization of Pacific seamounts: A preliminary polar curve for the northeastern Pacific, J. Geophys. Res., 75, 2035-2061, 1970.

Gordon, R. G., Late Cretaceous apparent polar wander path of the Pacific plate: evidence a rapid shift of the Pacific hotspots with respect to the paleomagnetic axis, Geophys. Res. Lett., 10, 709-712, 1983.

Gordon, R. G., Test for bias in paleomagnetically determined paleolatitudes from Pacific plate Deep Sea Drilling Project sediments, J. Geophys. Res., 95, 8397-8404, 1990.

Grossling, B. F., Seamount magnetism, in The Sea, vol. 4, edited by A. E. Maxwell, Wiley-Interscience, New York, 1970.

Haggerty, J. A., S. O. Schlanger, and I. Premoli-Silva, Late Cretaceous and Eocene volcanism in the southern Line Island and implications for hotspot theory, Geology, 10, 433-437, 1982.

Hamilton, E. L., Sunken Islands of the mid-Pacific mountains, Mem. Geol. Soc. Am., 64, 97 pp., 1956.

Harrison, C. G. A., A seamount with a non-magnetic top, Geophysics, 36, 349-357, 1971.

Harrison, C. G. A., R. D. Jarrard, V. VACquier, and R. L. Larson, Paleomagnetism of Cretaceous Pacific seamounts, Geophys. J. R. Astron. Soc., 42, 859-882, 1975.

Henderson, L. J., Motion of the Pacific plate relative to the hotspots since the Jurassic and model of oceanic plateaus of the Farallon plate, Ph. D. dissertation, 321 pp., Northwestern University, Evanston, IL, 1985.

Henderson, L. J. and R. G. Gordon, Oceanic plateaus and the motion of the Pacific plate with respect to the hotspots (abstract), EOS Trans., American Geophysical Union, 62, p. 1028, 1981.

Hildebrand, J. A. and R. L. PARker, Paleomagnetism of Cretaceous Pacific seamounts revisited, J. Geophys. Res., 92, 12695-12712, 1987.

IAGA WORKING GROUP 1, International Geomagnetic Reference Field 1985, J. Geomag. Geoelectr., 37, 1157$1163,1985$.

ISEZAKI, N. and H. INOKUCHI, Magnetic field due to polygonal pyramidal bodies, J. Geomag. Geoelectr., 37, 1131-1140, 1985.

JARRARD, R. D. and S. SASAJIMA, Paleomagnetic synthesis for southeast Asia: constraints on plate motions, in The Tectonic and Geologic Evolution of Southeast Asian Seas and Islands, Geophys. Mon. Ser. vol. 23, edited by D. E. Hayes, pp. 293-317, AGU, Washington, D.C., 1980.

KANEOKA, I., K-Ar ages of seamounts along the Japan trench and the effect of acid leaching on the K-Ar age of a dredge submarine rock, Geochem. J., 5, 113-120, 1971.

Kent, D. V. and F. M. Gradstein, A Cretaceous and Jurassic geochronology, Geol. Soc. Am. Bull., 96, 1419$1427,1985$.

KoBAyAshi, K., Preliminary Report of the Hakuho Maru Cruise KH90-1, Ocean Research Institute University of Tokyo, 174pp., 1991.

Kobayashi, K., J. P. Cadet, J. Aubouin, J. Boulegue, J. Dubois, R. von Huene, L. Jolivet, T. Kanazawa, J. Kasahara, K. Koizumi, S. Lallemand, Y. Nakamura, G. Pautot, K. Suyehiro, S. Tani, H. Tokuyama, 
and T. YAmAzAKI, Normal faulting of the Daiichi-Kashima Seamount in the Japan Trench revealed by the Kaiko I cruise, Leg 3, Earth Planet. Sci. Lett., 83, 257-266, 1987.

Larson, R. L. and W. LowrIE, Paleomagnetic evidence for motion of the Pacific plate from Leg 32 basalts and magnetic anomalies, Init. Rept. DSDP, 32, 571-577, 1975.

Le Pichon, X., K. Kobayashi, J. P. Cadet, T. Iryama, K. Nakamura, G. Pautot, V. Renard, and the Kaiko SCIentific Crew, Project Kaiko-Introduction, Earth Planet. Sci. Lett., 83, 183-185, 1987.

Lincoln, J. M., M. S. Pringle, and I. Premoli-Silva, Early and late Cretaceous volcanism and reef -building in the Marshall Islands, in The Mesozoic Pacific, Geophys. Monogr., edited by M. S. Pringle, W. W. Sager, W. V. Sliter, and S. Stein, AGU, Washington, D.C., 1992 (in press).

Masalu, D. C. P., Magnetic anomalies of the Joban seamount chain in the Northwestern Pacific, M. Sc. Thesis, 81pp., University of Tokyo, 1991.

Masalu, D. C. P., K. Tamaki, M. Nakanishi, A. Oshida, and K. Kobayashi, Magnetic anomalies of the seamounts forming the Joban seamount chain, in 89th SGEPSS spring meeting abstracts, 1991a.

Masalu, D. C. P., K. TAMAKI, and K. Kobayashi, Magnetic anomalies of the Joban seamount chain in the northwestern Pacific, EOS Trans., American Geophysical Union, 72, 454, 1991b.

MCNutT, M., Nonuniform magnetization of seamounts: A least squares approach, J. Geophys. Res., 91, 3686$3700,1986$.

McNutt, M. K. and K. M. Fischer, The south Pacific superswell, in Seamounts, Islands and Atolls, Geophys. Monogr. B. H. Keating, P. Fryer, R. Batiza, and G. W. Boehlert, vol. 43, pp. 25-34, AGU, Washington D.C., 1987.

McNutt, M. K., E. I. Winterer, W. W. Sager, J. H. Natland, and G. Ito, The Darwin Rise: a Cretaceous superswell?, Geophys. Res. Lett., 17, 1101-1104, 1990.

Menard, H. W., Marine Geology of the Pacific, 271 pp., McGraw-Hill, New York, 1964.

Menard, H. W., Darwin Reprise, J. Geophys. Res., 89, 9960-9968, 1984.

Miles, P. R. and D. G. RoBerts, The magnetization of Rosemary Bank seamount, Rockall trough northeast Atlantic, Earth Planet. Sci. Lett., 54, 442-448, 1981.

Mogi, A. and K. Nishizawa, Breakdown of a seamount on the slope of the Japan Trench, Proc. Jpn. Acad., 56, 257-259, 1980.

Morgan, W. J., Convection plumes in the lower mantle, Nature, 230, 42-43, 1971.

Morgan, W. J., Hotspot tracks and the early rifting of the Atlantic, Tectonophys., 94, 123-139, 1983.

NAKANISHI, M., K. TAMAKI, and K. KoBAYASHI, Mesozoic magnetic anomaly lineations and seafloor spreading history of the Northwestern Pacific, J. Geophys. Res., 94, 15437-15462, 1989.

NAKanishi, M., K. TAmaki, and K. Kobayashi, A new Mesozoic isochron chart of the Northwestern Pacific ocean: Paleomagnetic and tectonic implications, Geophys. Res. Lett., 19, 693-696, 1992.

OzIMA, M., I. KANEOKA, and S. ARAMAKI, K-Ar ages of submarine basalts dredged from seamounts in the Western Pacific area and discussion of oceanic crust, Earth Planet. Sci. Lett., 8, 237-249, 1970.

Ozima, M., M. HondA, and K. SAITo, ${ }^{40} \mathrm{Ar}-{ }^{39} \mathrm{Ar}$ ages of guyots in the Western Pacific and discussion of their evolution, Geophys. J. R. astron. Soc., 51, 475-485, 1977.

Parker, R. L., L. Shure, and J. A. Hildebrand, The application inverse theory to seamount magnetism, Rev. Geophys., 25, 17-40, 1987.

Parsons, B. and J. G. Sclater, An analysis of the variation of ocean-floor bathymetry and heat flow with age, J. Geophys. Res., 82, 803-827, 1977.

Pautot, G., K. Nakamura, P. Huchon, J. Angelier, J. Bourgois, K. Fujioka, T. Kanazawa, Y. Nakamura, Y. Ogawa, M. Seguret, and A. Takeuchi, Deep-sea submersible survey in the Suruga, Sagami and Japan Trenches: preliminary results of the 1985 KAIKO cruise, Leg 2, Earth Planet. Sci. Lett., 83, 300-312, 1987.

PloufF, D., Gravity and magnetic fields of polygonal prisms and applications to magnetic terrain corrections, Geophysics, 41, 727-741, 1976.

Pringle, M. S., Age progressive volcanism in the Musicians seamounts: A test of the hot spot hypothesis for the Late Creatceous Pacific, in The Mesozoic Pacific, Geophys. Monogr., edited by M. S. Pringle, W. W. Sager, W. V. Sliter, and S. Stein, AGU, Washington, D.C., 1992 (in press).

Pringle, M. S. and G. Brent Dalrymple, Geochronological constraints on a possible hot spot origin for Hess Rise and the Wentworth seamount chain, in The Mesozoic Pacific, Geophys. Monogr., edited by M. S. Pringle, W. W. Sager, W. V. Sliter, and S. Stein, AGU, Washington, D.C., 1992 (in press).

Pringle, M. S., H. Staudigel and J. Gee, Jasper seamount: Seven million years of volcanism, Geology, 19, 364-368, 1991.

Richards, M. L., V. VACQUier, and G. D. VAnoorhis, Calculation of the magnetization of uplifts from combining topographic and magnetic surveys, Geophysics, 32, 678-707, 1967.

ReA, D. K. and T. L. VAllier, Two Cretaceous volcanic episodes in the western Pacific Ocean, Geol. Soc. Amer. Bull., 94, 1430-1437, 1983. 
Sager, W. W., Seamount paleomagnetism and Pacific plate Tectonics, Ph. D Thesis, 472 pp., University of Hawaii, Honolulu, 1983.

SAger, W. W., Paleomagnetism of Abbott seamount and Implications for the latitudinal drift of the Hawaii hotspot, J. Geophys. Res., 89, 6271-6284, 1984.

SAGER, W. W., Seamount age estimates from paleomagnetism and their implications for the history of volcanism on the Pacific plate, in Geology and Offshore Mineral Resources of the Central Pacific Basin, edited by B. H. Keating and B. Bolton, Circum-Pacific Council for Energy and Mineral Resources, Earth Sci. Ser., vol. 14, 21-37, 1992.

SAgER, W. W. and B. H. KeAting, Paleomagnetism of Line Islands seamounts: Evidence for late Cretaceous and early tertiary volcanism, J. Geophys. Res., 89, 11135-11151, 1984.

Sager, W. W. and M. S. Pringle, Paleomagnetic constraints on the origin and evolution of the Musicians and South Hawaii seamounts, Central Pacific Ocean, in Seamounts, Islands and Atolls, Geophys. Monogr. Ser. 43, edited by B. H. Keating, P. Fryer, R. Batiza, and G. W. Boehlert, pp. 133-162, AGU, Washington, D.C., 1987.

Sager, W. W. and M. S. Pringle, Mid-Cretaceous to early Tertiary Apparent Polar Wander Path of the Pacific Plate, J. Geophys. Res., 93, 11753-11771, 1988.

Sager, W. W. and M. S. Pringle, Paleomagnetic evidence for Cretaceous age of two volcanoes on the South flank of the Island of Hawaii, Geophys. Res. Lett., 17, 2445-2448, 1990.

Sager, W. W., R. A. Duncan, and D. W. HAndschumacher, Paleomagnetism of the Japanese and Marcus-Wake Seamounts, Western Pacific Ocean, in The Mesozoic Pacific, Geophys. Monogr., edited by M. S. Pringle, W. W. Sager, W. V. Sliter, and S. Stein, AGU, Washington, D. C., 1992 (in press).

Schimke, G. R. and C. G. Bufe, Geophysical description of a Pacific Ocean seamount, J. Geophys. Res., 73, 559-569, 1968.

SChlanger, S. O. and I. Premoli-Silva, Tectonic, volcanic, and paleogeographic implications of redeposited reef faunas of Late Cretaceous and Tertiary age from the Nauru Basin and Line Islands, Initial Reports of the Deep Sea Drilling Project, vol. 61,p. 817-827, 1981.

SChlanger, S. O., J. F. CAMPBell, and M. W. JACKSOn, Post-Eocene subsidence of the Marshall Islands recorded by drowned atolls on Harrie and Sylvania guyots, in Seamounts, Islands and Atolls, Geophys. Monogr. Ser. 43, edited by B. H. Keating, P. Fryer, R. Batiza, and G. W. Boehlert, pp. 165-174, AGU, Washington, D.C., 1987.

Schlanger, S. O., H. C. Jenkyns, and I. Premoli-Silva, Volcanism and vertical tectonics in the Pacific basin related to global Cretaceous transgressions, Earth Planet. Sci. Lett., 52, 435-449, 1981.

Shure, L., R. L. PARker, and E. M. Robinson, Interpreting seamount magnetic anomalies, EoS Trans. AGU, 65, 1079, 1984.

TAKIGAMI, Y., I. KANEOKA, T. ISHII, and Y. NAKAMURA, ${ }^{40} \mathrm{Ar}-{ }^{39} \mathrm{Ar}$ ages of igneous rocks recovered from DiichiKashima and Erimo seamounts during the KAIKO project, Palaeogeogr. Palaeoclim. Palaeoecol., 71, 71-81, 1989.

TALWANI, M., Computation with the help of a digital computer of magnetic anomalies caused by bodies of arbitrary shape, Geophysics, 30, 797-817, 1965.

Tarduno, J. A., W. V. Sliter, L. Kroenke, M. Leckie, H. Mayer, J. J. Mahoney, R. Musgrave, M. Storey, and E. L. Winterer, Rapid formation of Ontong Java Plateau by Aptian mantle plume volcanism, Science, 254, 399-403, 1991.

TOMODA, Y., Reference book for gravity, magnetic and bathymetric data of the Pacific ocean and adjacent seas, 1963-71 Univ. of Tokyo Press, 158 pp., 1974.

Tucholke, B. and N. C. Sмоот, Evidence for age and evolution of Corner seamounts and Great Meteor Seamount Chain from multibeam bathymetry, J. Geophys. Res., 95, 17555-17569, 1990.

UEDA, Y., Geomagnetic study on seamounts Daiiti-Kashima and Katori with special reference to a subduction process of Daiiti-Kashima, J. Geomag. Geoelectr., 37, 601-625, 1985.

UEDA, Y., Geophysical study of two seamounts near Minami-Tori sima (Marcus) Islands, Western Pacific Ocean, J. Geomag. Geoelectr., 40, 1481-1501, 1988.

UyedA, S. and M. L. Richards, Magnetization of four Pacific seamounts near the Japanese Islands, Bull. Earthquake Res, Inst., Univ. Tokyo, 44, 179-213, 1966.

VACQUIER, V., A machine method for computing the magnetization of a uniformly magnetized body from its shape and a magnetic survey, in Benedum Earth Magnetism Symposium, pp. 123-137, University of Pittsburgh Press, Pittsburgh, Pa., 1962.

VAcquier, V. and S. Uyeda, Paleomagnetism of nine seamounts in the Western Pacific and three volcanoes in Japan, Bull. Earthquake Res. Inst., Univ. Tokyo, 45, 815-848, 1967.

VAN WAASBergen, R. J. and E. L. Winterer, Summit geomorphology of western Pacific guyots, in The Mesozoic Pacific, Geophys. Monogr., edited by M. S. Pringle, W. W. Sager, W. V. Sliter, and S. Stein, AGU, 
Washington, D.C., 1992 (in press).

Verhoef, J. and J. ARKANI-HAmed, Chemical remanent magnetization of oceanic crust, Geophys. Res. Lett., 17, 1945-1948, 1990.

Winterer, E. L., Anomalies in the tectonic evolution of the Pacific, in The Geophysics of the Pacific Ocean Basin and Its Margin, Geophys. Monogr. Ser., vol. 19, edited by G. H. Sutton, M. H. Manghnani, and R. Moberly, pp. 269-278, AGU, Washington, D.C., 1976.

Winterer, E. L., R. A. Duncan, M. K. McNutt, J. H. Natland, I. Premoli-Silva, W. W. Sager, W. V. Sliter, R. van WaAsbergen, and C. J. Wolfe, Creataceous guyots in the northwest Pacific: an overview of their geology and geophysics, in The Mesozoic Pacific, Geophys. Monogr., edited by M. S. Pringle, W. W. Sager, W. V. Sliter, and S. Stein, AGU, Washington, D. C., 1992 (in press).

Wolfe, C. J. and M. K. MCNutT, Compensation of Cretaceous seamounts of the Darwin Rise, northwest Pacific Ocean, J. Geophys. Res., 96, 2363-2374, 1991.

YAMAZAKI, T., Magnetization of Erimo seamount, J. Geomag. Geoelectr., 40, 715-728, 1988. 